\title{
Hydrologic control of the oxygen isotope ratio of ecosystem respiration in a semi-arid woodland
}

\author{
J. H. Shim ${ }^{1}$, H. H. Powers ${ }^{1}$, C. W. Meyer ${ }^{1}$, A. Knohl ${ }^{2}$, T. E. Dawson ${ }^{3}$, W. J. Riley ${ }^{4}$, W. T. Pockman ${ }^{5}$, and N. McDowell \\ ${ }^{1}$ Earth and Environmental Sciences Division, Los Alamos National Laboratory, MS-J495, Los Alamos, NM 87545, USA \\ ${ }^{2}$ Chair of Bioclimatology, Georg-August University of Göttingen, Göttingen, Germany \\ ${ }^{3}$ Department of Integrative Biology, University of California, Berkeley, CA, USA \\ ${ }^{4}$ Earth Sciences Division, Lawrence Berkeley National Laboratory, Berkeley, CA, USA \\ ${ }^{5}$ Department of Biology, University of New Mexico, Albuquerque, NM 87131-0001, USA
}

Correspondence to: J. H. Shim (jeehshim@gmail.com)

Received: 19 September 2012 - Published in Biogeosciences Discuss.: 2 January 2013

Revised: 8 May 2013 - Accepted: 18 June 2013 - Published: 23 July 2013

\begin{abstract}
We conducted high frequency measurements of the $\delta^{18} \mathrm{O}$ value of atmospheric $\mathrm{CO}_{2}$ from a juniper (Juniperus monosperma) woodland in New Mexico, USA, over a fouryear period to investigate climatic and physiological regulation of the $\delta^{18} \mathrm{O}$ value of ecosystem respiration $\left(\delta_{\mathrm{R}}\right)$. Rain pulses reset $\delta_{\mathrm{R}}$ with the dominant water source isotope composition, followed by progressive enrichment of $\delta_{\mathrm{R}}$. Transpiration $\left(E_{\mathrm{T}}\right)$ was significantly related to post-pulse $\delta_{\mathrm{R}}$ enrichment because the leaf water $\delta^{18} \mathrm{O}$ value showed strong enrichment with increasing vapor pressure deficit that occurs following rain. Post-pulse $\delta_{R}$ enrichment was correlated with both $E_{\mathrm{T}}$ and the ratio of $E_{\mathrm{T}}$ to soil evaporation $\left(E_{\mathrm{T}} / E_{\mathrm{S}}\right)$. In contrast, the soil water $\delta^{18} \mathrm{O}$ value was relatively stable and $\delta_{\mathrm{R}}$ enrichment was not correlated with $E_{\mathrm{S}}$. Model simulations captured the large post-pulse $\delta_{\mathrm{R}}$ enrichments only when the offset between xylem and leaf water $\delta^{18} \mathrm{O}$ value was modeled explicitly and when a gross flux model for $\mathrm{CO}_{2}$ retro-diffusion was included. Drought impacts $\delta_{\mathrm{R}}$ through the balance between evaporative demand, which enriches $\delta_{\mathrm{R}}$, and low soil moisture availability, which attenuates $\delta_{\mathrm{R}}$ enrichment through reduced $E_{\mathrm{T}}$. The net result, observed throughout all four years of our study, was a negative correlation of post-precipitation $\delta_{\mathrm{R}}$ enrichment with increasing drought.
\end{abstract}

\section{Introduction}

Terrestrial ecosystems play an important role in global carbon cycling, and atmospheric oxygen isotope composition of $\mathrm{CO}_{2}\left(\delta_{\mathrm{a}}\right)$ has emerged as a promising tool to detect biosphere-atmosphere $\mathrm{CO}_{2}$ fluxes at tissue, ecosystem, regional and global scales (Francey and Tans, 1987; Yakir and Wang, 1996; Tans and White, 1998; Farquhar et al., 1993; Buenning et al., 2011; Cuntz et al., 2003a; Welp et al., 2011). $\delta_{\mathrm{a}}$ has been used to distinguish the contributions of photosynthesis and respiration (Tans and White, 1998; Yakir and Wang, 1996) and of nocturnal foliar and soil respiration (Bowling et al., 2003a) to net ecosystem exchange. The $\delta^{18} \mathrm{O}$ value of terrestrial $\mathrm{CO}_{2}$ fluxes $\left(\delta_{\mathrm{R}}\right)$ may provide a stronger terrestrial signal than $\delta^{13} \mathrm{C}$ in some ecosystems (Fung et al., 1997; Ogée et al., 2004), but prediction of $\delta_{\mathrm{R}}$ is complex (Still et al., 2009) because it depends on prediction of both ecosystem water and C dynamics (Riley et al., 2003, 2005; Lai et al., 2006). The utility of oxygen isotopes in carbon cycle research can be improved, however, by a better understanding of plant physiological effects on the gross and net leaf fluxes of $\mathrm{C}^{18} \mathrm{O}^{16} \mathrm{O}$ (Flanagan et al., 1997; Gillon and Yakir, 2000; Cernusak et al., 2004).

$\delta_{\mathrm{R}}$ depends on the ${ }^{18} \mathrm{O}$ composition of the net $\mathrm{CO}_{2}$ effluxes from foliage, stem, and soils. These effluxes are strongly influenced by the ${ }^{18} \mathrm{O}$ compositions of their respective water pools through oxygen atom exchange between $\mathrm{CO}_{2}$ and $\mathrm{H}_{2} \mathrm{O}$ after equilibrium and diffusive fractionation (Brenninkmeijer et al., 1983; Tans, 1998; Farquhar et al., 1993). Carbonic anhydrase (CA) catalyzes this $\mathrm{CO}_{2}-\mathrm{H}_{2} \mathrm{O}$ isotopic equilibration inside foliage (Flanagan et al., 1997) and soil (Riley et al., 2002; Seibt et al., 2006; Wingate et al., 2009).

The $\delta^{18} \mathrm{O}$ value of near-surface soil water $\left(\delta_{\mathrm{SW}}\right)$ is often reset to the isotopic content of precipitation, which varies strongly with condensation temperature, storm origin, and 
storm tracks (Rozanski et al., 1982; Wingate et al., 2010). Subsequently, a vertical gradient in $\delta_{\mathrm{SW}}$ is often established because soil evaporation leads to isotopic enrichment (increasing $\delta^{18} \mathrm{O}$ value; Sharp, 2005) in the upper layers (Walker et al., 1988; Mathieu and Bariac, 1996). Soil water that is taken up by plant roots is transported through the xylem unfractionated in most terrestrial ecosystems (Dawson and Ehleringer, 1991). Leaf water becomes enriched relative to xylem water because of fractionation during evapotranspiration (Wang and Yakir, 1995; Roden and Ehleringer, 1999; Flanagan et al., 1997). At night, leaf water can become more enriched than that predicted by the Craig-Gordon model, due to the lag in relaxation of the daytime leaf water enrichment toward the nighttime value (Cernusak et al., 2002; Farquhar and Cernusak, 2005). Cuntz et al. (2003b) incorporated such a lag into a global model of $\delta^{18} \mathrm{O}$ value in atmospheric $\mathrm{CO}_{2}$. They concluded that the leaf-respired $\delta^{18} \mathrm{O}$ value becomes further enriched above source water due to $\mathrm{CO}_{2}$ retro-diffusion (the process where $\mathrm{CO}_{2}$ enters foliage through stomata, equilibrates with leaf water, and escapes from the leaf without altering the net $\mathrm{CO}_{2}$ flux; Cernusak et al., 2004). Lastly, assuming an accelerated soil hydration rate from soil surface CA activity improved agreement between predicted and observed ${ }^{18} \mathrm{O}$ composition of atmospheric $\mathrm{CO}_{2}$ (Wingate et al., 2009).

$\delta_{\mathrm{R}}$ is impacted by evaporative enrichment of ecosystem water pools. Evapotranspiration drives greater isotopic enrichment in foliage than in soils due to the much smaller water pool of foliage. This enrichment results in foliar respiration being more ${ }^{18} \mathrm{O}$ enriched than soil respiration, and the isotopic disequilibrium between the $\delta^{18} \mathrm{O}$ values of soil and leaf-respired $\mathrm{CO}_{2}$ is enhanced during dry periods (Wingate et al., 2010). For example, the $\delta^{18} \mathrm{O}$ values of branch and soil respiration increased during a post-precipitation dry period by $170 \%$ and $18 \%$ (Vienna Pee Dee Belemnite- $\mathrm{CO}_{2}$ ), respectively, in a Pinus dominated ecosystem in Europe (Wingate et al., 2010). Thus, $\delta_{\mathrm{a}}$ may carry a strong signal of drought impacts on the hydrology of terrestrial systems.

A reasonable hypothesis is that $\delta_{\mathrm{R}}$ increases during seasonal droughts when precipitation $(P)$ minus potential evapotranspiration ( $E_{\mathrm{P}}$; Ellis et al., 2010) is most negative. Testing this hypothesis requires long-term datasets to capture a large range of $P-E_{\mathrm{P}}$. A further reasonable hypothesis is that drought imparts a $\delta_{\mathrm{R}}$ enrichment dependent on the ratio of canopy transpiration to soil evaporation $\left(E_{\mathrm{T}} / E_{\mathrm{S}}\right)$ because of their differential responses to drought (Wingate et al., 2010). $E_{\mathrm{T}}$ and $E_{\mathrm{S}}$ represent the two main fluxes of water from the ecosystem to the atmosphere. The $E_{\mathrm{T}} / E_{\mathrm{S}}$ ratio is fundamentally important because it is mechanistically linked to vegetation and ecosystem water balance processes and is sensitive to disturbances such as climate extremes and woody encroachment (Huxman et al., 2005). Therefore, the magnitude of $\delta_{\mathrm{R}}$ enrichment over the several days after pulse events should be linked to $E_{\mathrm{T}}$ and $E_{\mathrm{S}}$ because these fluxes impact the $\delta^{18} \mathrm{O}$ values of source water pools (i.e., leaves and soil water) with which $\mathrm{CO}_{2}$ interacts.

To our knowledge, no study has combined long-term $\delta_{\mathrm{R}}$, $P-E_{\mathrm{P}}$, and $E_{\mathrm{T}} / E_{\mathrm{S}}$ observations with an analysis of terrestrial ecosystem drought response. $E_{\mathrm{T}} /\left(E_{\mathrm{S}}+E_{\mathrm{T}}\right)$ has been estimated from observations for a relatively small number of locations in water-limited regions, and those field estimates vary greatly in methodology (Reynolds et al., 2000, Wilson et al., 2001). There have been a few high-resolution, continuous monitoring studies of $\delta_{\mathrm{R}}$ (Griffis et al., 2005; Welp et al., 2006; Wingate et al., 2010), but none from arid ecosystems that would be expected to strongly exhibit drought signals. Semi-arid woodlands in the southwestern USA are dominated by pulse-driven precipitation patterns and prolonged and severe drought periods (Seager et al., 2007; Rauscher et al., 2008); thus a logical expectation is that these woodlands exhibit large variation in $\delta_{\mathrm{R}}, P-E_{\mathrm{P}}$, and $E_{\mathrm{T}} / E_{\mathrm{S}}$.

We measured $\delta_{\mathrm{R}}$ in a juniper (Juniperus monosperma) woodland over a four-year period to investigate precipitationpulse-driven eco-hydrological responses. Along with direct measurements of $E_{\mathrm{T}}$, we improved and applied ISOLSM (Riley et al., 2002), an isotope-enabled land-surface model, to estimate $E_{\mathrm{S}}$ and interpret $\delta_{\mathrm{R}}$ observations. We hypothesized that (1) $\delta_{\mathrm{R}}$ would be related to $P-E_{\mathrm{P}}$; however, (2) this relationship would be moderated by rainfall-pulsedriven changes in $E_{\mathrm{T}}$ or $E_{\mathrm{T}} / E_{\mathrm{S}}$. Our overarching goal is to move towards better understanding of the mechanisms determining the $\delta^{18} \mathrm{O}$ compositions of terrestrial $\mathrm{CO}_{2}$ fluxes and the atmosphere, allowing for potential use of these signatures for monitoring the impacts of drought on terrestrial ecosystems.

\section{Methods}

\subsection{Field site}

The field site is a piñon pine-one-seed juniper (Pinus edulisJuniperus monosperma) woodland located in northern New Mexico at Los Alamos National Laboratory $\left(35.85^{\circ} \mathrm{N}\right.$, $106.27^{\circ} \mathrm{W}$, elevation $2140 \mathrm{~m}$ ). Approximately $97 \%$ of the mature piñon trees died in October 2002 (Breshears et al., 2005; McDowell et al., 2008a), resulting in a large necromass component to the ecosystem. The understory is dominated by $\mathrm{C}_{3}$ forbs that have increased substantially since the piñon mortality, with a minor component $(<10 \%$ cover) of native $\mathrm{C}_{4}$ grass (Bouteloua gracilis). Average leaf area index of the understory during the growing season is $\sim 0.25 \mathrm{~m}^{2} \mathrm{~m}^{-2}$ and juniper leaf area index is $\sim 1.1 \mathrm{~m}^{2} \mathrm{~m}^{-2}$; maximum canopy height is $\sim 5.5 \mathrm{~m}$ and stand density is about 371 trees ha $^{-1}$ (McDowell et al., 2008a). The site is located on a $\sim 200 \mathrm{~m}$ wide mesa with a slope of $\sim 5 \%$. The soils are a Hackroy clay loam derived from volcanic tuff, with depths ranging from 30 to $130 \mathrm{~cm}$. The climate is continental with warm summers and cold winters. Mean annual precipitation is 
$400 \mathrm{~mm}$ and exhibits a bimodal distribution between winter snowfall and summer monsoon showers. This has been the site of extensive research on ecology and hydrology (Lajtha and Barnes, 1991; Breshears et al., 1997; Newman and Robinson, 2005; Rich et al., 2008) and on the isotopic fluxes associated with photosynthesis and respiration at leaf, soil, and ecosystem scales (McDowell et al., 2008b; Bickford et al., 2009, 2010; Powers et al., 2010, Shim et al., 2011).

\subsection{Micrometeorology and $E_{\mathrm{T}}$ calculation}

We collected meteorological measurements at $30 \mathrm{~s}$ and recorded averages every $30 \mathrm{~min}$ including air temperature, relative humidity $(\mathrm{RH})$, soil water content $(\mathrm{SWC})$ at $2 \mathrm{~cm}$ depth, and rainfall (Texas Electronics, Texas, USA). Soil water content was also measured at depths of $20-100 \mathrm{~cm}$ twice per month using neutron probes (503DR Hydrophobe Neutron Moisture Probes, Campbell Pacific Nuclear, Inc., Pacheco, CA, USA). Pre-dawn leaf water potential $\left(\Psi_{\mathrm{pd}}\right)$ was measured once per month using a Scholander-type pressure chamber (PMS Instruments Co., Corvallis, OR, USA) on six mature juniper trees.

Canopy-scale transpiration, $E_{\mathrm{T}}$, was estimated by measuring sap flux density with Granier heat dissipation probes (Granier, 1987; Phillips and Oren, 2001). A detailed description of sap flux methodology is described in Shim et al. (2011). Transpiration was scaled to the canopy level as

$E_{\mathrm{T}}=J_{\mathrm{s}} A_{\mathrm{s}} / A_{\mathrm{g}}$,

where $J_{\mathrm{S}}$ is sap flux $\left(\mathrm{g} \mathrm{m}^{-2} \mathrm{~s}^{-1}\right), A_{\mathrm{S}}$ is sapwood area $\left(\mathrm{m}^{2}\right)$, and $A_{\mathrm{g}}$ is the ground area $\left(\mathrm{m}^{2}\right)$. Site-specific $A_{\mathrm{s}} / A_{\mathrm{g}}$ was from McDowell et al. (2008a) and did not change considerably during the study due to the low growth rate of these trees.

\subsection{Incorporation of the Isotope Land-Surface Model (ISOLSM)}

The use of isotope-enabled land models to interpret ${ }^{18} \mathrm{O}$ values of ecosystem water and $\mathrm{CO}_{2}$ fluxes at the site level is fraught with potential uncertainties (Ogée et al., 2004) stemming from challenges in (1) simulating the underlying bulk water and $\mathrm{CO}_{2}$ fluxes (Schwalm et al., 2010; Tang and Zhuang, 2008); (2) equilibrium and kinetic fractionations (Cappa et al., 2003); (3) above-canopy isotopic forcing (Welker, 2000); (4) vertical soil distributions of ${ }^{18} \mathrm{O}$ and $\mathrm{CO}_{2}$ production (Riley et al., 2002; Riley, 2005); and (5) leaf water ${ }^{18} \mathrm{O}$ and interactions with $\mathrm{CO}_{2}$ (Cernusak et al., 2003; Farquhar and Cernusak, 2005). The problem becomes even more acute when isotope-enabled land models are integrated into global models (e.g., Buenning et al., 2012; Wingate et al., 2009). Despite these complications, we contend these models can be helpful to investigate relationships between forcing and net isotope exchanges with the atmosphere, as long as an awareness of these uncertainties is maintained.
With that philosophy in mind, we applied ISOLSM (Riley et al., 2002) to investigate land-to-atmosphere $\mathrm{C}^{18} \mathrm{OO}$ exchanges in the period immediately following precipitation events. ISOLSM has been used in a number of studies to evaluate controls on the ${ }^{18} \mathrm{O}$ composition of ecosystem $\mathrm{C}$ and $\mathrm{H}_{2} \mathrm{O}$ exchanges at site, regional, and global scales (Riley et al., 2002, 2003; Riley, 2005; Buenning et al., 2011; Henderson-Sellers et al., 2006; Lai et al., 2006; McDowell et al., 2008b; Still et al., 2005, 2009).

Here, we briefly describe the methods used in ISOLSM; details of the model formulation can be found in Riley et al. (2002). In addition to simulating fluxes of $\mathrm{CO}_{2}$, $\mathrm{H}_{2} \mathrm{O}$, radiation, sensible heat, and latent heat, ISOLSM predicts separately each component of the ecosystem $\mathrm{CO}_{2}$ and $\mathrm{H}_{2} \mathrm{O}$ isotope effluxes. Site-level climate observations sufficient to force ISOLSM continuously for the three years of this study were unavailable. Therefore, the necessary inputs (wind speed, humidity, temperature, pressure, solar and long-wave radiation) to drive ISOLSM were obtained from the North American Regional Reanalysis product (NARR; http://www.emc.ncep.noaa.gov/mmb/rreanl/). The NARR is a meteorological assimilation framework designed to produce consistent climate data for the North American region. It assimilates, at a $3 \mathrm{~h}$ time step, a suite of high-resolution meteorological observations into a coupled atmosphere (Eta) and land (NOAH) model. ISOLSM interpolates the resulting climate forcing to its half-hour internal time step, so no gap filling of climate forcing was required.

As with almost every other long-term $\mathrm{C}$ and $\mathrm{H}_{2} \mathrm{O}$ isotope modeling exercise ever performed, we did not have continuously observed $\delta^{18} \mathrm{O}$ values of precipitation or above-canopy atmospheric humidity. For this study, as in Still et al. (2009), we used the monthly mean precipitation $\delta^{18} \mathrm{O}$ values averaged over 2-5 yr from analyses of archived water samples collected by the EPA National Atmospheric Deposition Program (NADP) network (Lynch et al., 1995) between 1980 and 1990 and interpolated across the US (Welker, 2000). Many factors affect the $\delta^{18} \mathrm{O}$ value of vapor $\left(\delta^{18} \mathrm{Ov}\right.$; Lee et al., 2006; Helliker et al., 2002; Lai et al., 2006; White and Gedzelman, 1984). We set $\delta^{18} \mathrm{Ov}$ to be in a temperaturedependent isotopic equilibrium with the most recent precipitation event (Still et al., 2009). We note that the sensitivity of ecosystem-atmosphere $\mathrm{C}^{18} \mathrm{OO}$ exchanges to diurnal variations in $\delta^{18} \mathrm{Ov}$ is relatively small (Riley et al., 2003). Accelerated $\mathrm{CO}_{2}-\mathrm{H}_{2} \mathrm{O}$ isotopic exchange (by carbonic anhydrase) in soils and foliage is an important factor impacting $\delta_{\mathrm{R}}$. We set the $\mathrm{CO}_{2}-\mathrm{H}_{2} \mathrm{O}$ isotopic hydration to $100 \%$ (Wingate et al., 2009; also see Farquhar and Cernusak, 2012) because seasonal and temporal variability in hydration activity is unknown. We set the soil setting point depth to $0-2.5 \mathrm{~cm}$ soil depth and applied a $7.2 \%$ o diffusive offset reflecting disequilibrium between $\mathrm{CO}_{2}$ and water near the surface (Miller et al., 1999).

We incorporated the one-way flux model proposed by Cernusak et al. (2004) to calculate the $\delta^{18} \mathrm{O}$ value of leaf $\mathrm{CO}_{2}$ 
fluxes $\left(\delta_{\mathrm{LR}}\right)$ :

$\delta_{\mathrm{LR}}=\frac{\theta\left[\delta_{\mathrm{CW}}\left(1+\varepsilon_{\mathrm{W}}\right)+\varepsilon_{\mathrm{w}}\right]+(1-\theta) \delta_{C 0}-\frac{C_{\mathrm{a}}}{C_{\mathrm{c}}}\left(\delta_{\mathrm{a}}-\bar{a}\right)-\bar{a}}{(1+\bar{a})\left(1-\frac{C_{\mathrm{a}}}{C_{\mathrm{c}}}\right)}$,

where $\theta$ is the proportion of chloroplast $\mathrm{CO}_{2}$ that is isotopically equilibrated with chloroplast water (assumed to be 1 for the simulations here); $\delta_{\mathrm{CW}}, \delta \mathrm{c}_{0}$, and $\delta_{\mathrm{a}}$ are the $\delta^{18} \mathrm{O}$ values of chloroplast water $(\%)$, of $\mathrm{CO}_{2}$ in the chloroplast that has not equilibrated with local water, and the $\mathrm{CO}_{2}$ mole fractions in the ambient atmosphere, respectively; $C_{\mathrm{a}}$ and $C_{\mathrm{c}}$ are the $\mathrm{CO}_{2}$ in the ambient air and in the chloroplasts $\left(\mu \mathrm{mol} \mathrm{mol}^{-1}\right)$, respectively; and $\varepsilon_{\mathrm{w}}$ is the equilibrium ${ }^{18} \mathrm{O}$ fractionation between $\mathrm{CO}_{2}$ and water that is dependent on temperature (Brenninkmeijer et al., 1983). $\bar{a}$ is the weighted mean discrimination against $\mathrm{C}^{18} \mathrm{OO}$ for diffusion from the chloroplast to the atmosphere (Farquhar and Lloyd, 1993):

$\bar{a}=\frac{\left(C_{\mathrm{c}}-C_{\mathrm{i}}\right) a_{\mathrm{w}}+\left(C_{\mathrm{i}}-C_{\mathrm{s}}\right) a+\left(C_{\mathrm{s}}-C_{\mathrm{a}}\right) a_{\mathrm{b}}}{C_{\mathrm{c}}-C_{\mathrm{a}}}$,

where $a_{\mathrm{w}}$ is the summed discriminations against $\mathrm{C}^{18} \mathrm{OO}$ during liquid phase diffusion and dissolution $(0.8 \%) ; a$ and $a_{\mathrm{b}}$ are the discriminations against $\mathrm{C}^{18} \mathrm{OO}$ during diffusion through the stomata and the boundary layer (8.8 and 5.8\%o, respectively); and $C_{\mathrm{i}}$ and $C_{\mathrm{s}}$ are $\mathrm{CO}_{2}$ in the leaf intercellular spaces and at the leaf surface $\left(\mu \mathrm{mol} \mathrm{mol}^{-1}\right)$, respectively.

We imposed a two-hour turnover time to the leaf water pool to account for the delayed equilibrium of leaf water with xylem water after transpiration ceases (Cuntz et al., 2003a; Farquhar and Cernusak, 2005; Lai et al., 2006). We used the model default value of minimum nighttime stomatal conductance (Bonan, 1996), which was supported by limited direct measurements (data not shown). We discuss the uncertainty resulting from these assumptions in the Discussion section.

We calculated the fractional contribution of each isoflux, i.e., leaf, soil, and stem, to the total ecosystem isoflux from the specific sources predicted by ISOLSM by multiplying the $\delta^{18} \mathrm{O}$ values of leaf, soil and stem $\mathrm{CO}_{2}$ fluxes by leaf, soil, and stem respiration rates, respectively.

\subsection{Drought index}

We used the difference between precipitation $(P)$ and estimated potential evapotranspiration $\left(E_{\mathrm{P}}\right)$ as a hydroclimatic index. We employed the Hamon (1961) method for $E_{\mathrm{P}}$ estimation.

$E_{\mathrm{P}}=13.97 D^{2} P_{\mathrm{t}}$,

where $E_{\mathrm{P}}$ is potential evapotranspiration $\left(\mathrm{mm} \mathrm{day}^{-1}\right), D$ is the number of daylight hours in units of $12 \mathrm{~h}$ for a given day, and $P_{\mathrm{t}}$ is the saturated water vapor density term calculated by

$P_{\mathrm{t}}=\frac{4.95 e^{0.062 T_{\mathrm{a}}}}{100}$, where $T_{\mathrm{a}}$ is daily mean air temperature $\left({ }^{\circ} \mathrm{C}\right)$. This index is well suited for regions with high interannual variability and extremely warm seasons during which evaporative loss dominates the hydrologic budget despite significant precipitation (Ellis et al., 2010).

\subsection{Tunable diode laser system}

A description of the tunable diode laser absorption spectrophotometer (TDL, TGA100A, Campbell Scientific Instruments, Logan, UT, USA) operation and sampling system is provided in Shim et al. (2011). Briefly, air samples were continuously collected from the canopy airspace of the piñonjuniper woodland at $0.05,1.0,1.5$ and $3.0 \mathrm{~m}$ height. The fetch for the sample area is representative of the local vegetation at our sampling location because the (dead) piñonjuniper ecosystem extends for approximately $73 \mathrm{~km}^{2}$ around the tower site. The lead salt laser within our TDL system was tuned to absorption lines of $2308.225 \mathrm{~cm}^{-1}, 2308.171 \mathrm{~cm}^{-1}$, and $2308.416 \mathrm{~cm}^{-1}$ for ${ }^{12} \mathrm{CO}_{2},{ }^{13} \mathrm{CO}_{2}$, and $\mathrm{C}^{12} \mathrm{O}^{18} \mathrm{O}^{16}$, respectively. The TDL sampled two calibration cylinders for $35 \mathrm{~s}$ each followed by four sample inlets and one quality control cylinder for $34 \mathrm{~s}$ each, resulting in a sample collected for each height every four minutes. The first $20 \mathrm{~s}$ of all samples were discarded to omit transients associated with valve switching and to ensure complete purging of the sample cell of the previous sample. To assess the net error associated with $\mathrm{CO}_{2}$ and $\delta^{18} \mathrm{O}$ measurements, we sampled a quality control cylinder during each sample cycle. This cylinder was sampled with the piñon-juniper field inlets and treated as an unknown. Precisions ( $1 \sigma$ standard deviation) for the unknown cylinders were $0.18 \mathrm{mmol} \mathrm{mol}^{-1}$ for $\mathrm{CO}_{2}$ and $0.16 \%$ o for $\delta^{18} \mathrm{O}$ value $(n=6000)$.

A linear two-point gain and offset correction was applied to the sample data as described by Bowling et al., (2003b). Working calibration cylinders were propagated from World Meteorological Organization traceable gases obtained from the National Oceanic and Atmospheric Administration Earth System Research Lab; $\left[\mathrm{CO}_{2}\right]$ was from 344.88 to $548.16 \mu \mathrm{mol} \mathrm{mol}^{-1}$ and the $\delta^{18} \mathrm{O}$ value from -8.16 to $-16.42 \%$. The mole fractions of the isotopologues ${ }^{12} \mathrm{CO}_{2}$, ${ }^{13} \mathrm{CO}_{2}$ and ${ }^{12} \mathrm{C}^{18} \mathrm{O}^{16} \mathrm{O}$ within our calibration gases spanned the range observed in the field samples. The secondary standards (Scott-Marin, Inc., USA) were propagated weekly from our two primary standards throughout 2006 and analyzed for drift in $\mathrm{CO}_{2}$ and $\delta^{18} \mathrm{O}$ value within the cylinders. Cylinder drift was negligible, averaging $0.00001 \%$ day ${ }^{-1}$, with maximum drift of $0.00005 \%$ day $^{-1}$ ( $n=12$ cylinders). We switched to approximately monthly propagation of secondary cylinders beginning in 2007.

We employed a two-ended mixing model to estimate $\delta_{\mathrm{R}}$ (Keeling, 1958; Flanagan et al., 1996; Zobitz et al., 2006). $\delta_{\mathrm{R}}$ represents the ${ }^{18} \mathrm{O}$ composition of the net ecosystem flux associated with respiration as well as abiotic invasion flux between leaves and the atmosphere (Francey and Tans, 1987) 
and soils and the atmosphere (Tans, 1998). We used measurements of $\mathrm{CO}_{2}$ and ${ }^{18} \mathrm{O}$ taken between 20:00 and 04:00 $\mathrm{h}$ and data from four inlets located at $0.05,1.0,1.5$ and $3.0 \mathrm{~m}$ together to examine nightly $\mathrm{R}$. Model I regressions were used to avoid negatively skewed intercepts (Zobitz et al., 2006). To assess the stability of isotopic sources for each night, we compared Keeling intercepts to the isotopic mixing line proposed by Miller and Tans (2003) (MT2003 hereafter). The MT2003 approach estimates $R_{R}$ as the slope of a linear regression between the product of ${ }^{18} \mathrm{O}$ and $\left[\mathrm{CO}_{2}\right]$ versus $\left[\mathrm{CO}_{2}\right]$ and offers an advantage when the Keeling approach violates the assumption of a stable background (Miller and Tans, 2003; Lai et al., 2004). Determining ${ }_{R}$ from a Keeling or a MT2003 regression from model I regressions gave similar results for our 4 yr data record $\left(r^{2}=0.99\right.$, see Fig. A5); therefore we retained our analysis via the Keeling approach. An independent check on the assumption of stable source values was conducted using ISOLSM, which revealed that the sources were relatively stable (mean standard error $(\% o)=1.5,0.1$, and 0.1 for ${ }^{18} \mathrm{O}$ of foliar, soil and stem respiration, respectively; see Fig. A6). We screened the data to include only values with ranges of $10 \mathrm{ppm}$ for $\mathrm{CO}_{2}$ and $2 \%$ for ${ }^{18} \mathrm{O}$ (Schaeffer et al., 2008). Using this filter, $64 \%$ of the nightly datasets were retained between April 2005 and October 2008.

\subsection{Analyses of pulse responses}

To determine the $\delta_{\mathrm{R}}$ response to precipitation pulses, we compared the $\delta_{\mathrm{R}}$ prior to a rain event to the subsequent days after that event and lasting up to 11 days, but not including subsequent rain events. The number of days after precipitation pulses was not significantly different by seasons ( $F=0.6, P=0.5$, ANOVA). Analysis within individual pulse events avoids confounding multiple precipitation events when analyzing the coupling of $\delta_{\mathrm{R}}$ to meteorological or physiological parameters. Rain events differed in $\delta^{18} \mathrm{O}$ value due to varying $\delta^{18} \mathrm{O}$ values of source water, temperature, and storm tracks (Rozanski et al., 1982); thus we report $\delta_{\mathrm{R}}$ responses to pulse precipitation events as the maximum $\delta_{\mathrm{R}}$ change over the week following a rain event (see an inset in Fig. 2). This approach allows comparison of the rate and magnitude of $\delta_{\mathrm{R}}$ changes after each pulse event across the four years.

We conducted correlation analyses of $\delta_{\mathrm{R}}$ with $E_{\mathrm{T}}$, vapor pressure deficit (VPD), RH, and SWC for each pulse event to determine the degree and speed of coupling between $\delta_{R}$ and hydrologic drivers (Bowling et al., 2002; Shim et al., 2011). We considered all possible subsets from 1 day after a pulse event up to 11 days, for all four years. We considered correlations ranging from instantaneous (e.g., $\delta_{\mathrm{R}}$ from day $x$ paired with $E_{\mathrm{T}}$ from day $x$ ) to lagged responses (e.g., $\delta_{\mathrm{R}}$ from day $x$ correlated with $E_{\mathrm{T}}$ from day $x-1, x-2$, and so on). Responses of $\delta_{\mathrm{R}}$ lagged up to 11 days behind driving variables were considered. The number of days used in these analyses varied with the length of time between rain events.
All correlations were conducted as linear regression models using the least squares method. We present all relationships with significance $(p)<0.1$ (Flanagan et al., 1996; McDowell et al., 2004; Shim et al., 2011).

\section{$2.7 \delta^{18} \mathrm{O}$ of precipitation, foliage, stem, and soils}

Samples of precipitation, foliage, stem, and soil water were collected and analyzed for ${ }^{18} \mathrm{O}$ composition in 2006 and 2007. Precipitation was collected from a sealed collection vial at the base of a rain funnel immediately after rain events. Foliage, stem and soil samples at 2, 7, and $10 \mathrm{~cm}$ were collected on a monthly basis as part of the Moisture Isotopes in the Biosphere and Atmosphere project. $\delta^{18} \mathrm{O}$ values of the soil water profile were measured at 5 depths: 2, 5, 7, 10 and $15 \mathrm{~cm}$ on day of year (DOY) 151 in 2006. Samples were cryogenically extracted on a vacuum line and analyzed with a Thermo Delta Plus XL mass spectrometer at the UC Berkeley stable isotope laboratory where long-term external precision (over more than $5 \mathrm{yr}$ ) is $\pm 0.24 \%$. All oxygen isotope ratios in this paper for water and $\mathrm{CO}_{2}$ are referenced to the Vienna Standard Mean Ocean Water (V-SMOW) scale (Coplen, 1996) and are presented in dimensionless units of $\%$.

\section{Results}

\subsection{Climate regimes over four years and associated patterns of $P-E_{\mathrm{P}}, E_{\mathrm{S}}, E_{\mathrm{T}} / E_{\mathrm{S}}$ and $\delta_{\mathrm{R}}$}

The pre-monsoon periods ( $\sim$ April-June) typically had relatively wet soil at depth $(20-40 \mathrm{~cm})$ from snowmelt but dry soil near the surface due to small precipitation inputs and long inter-pulse durations (Fig. 1a, Table A1.). There was substantial interannual variation, however, with a particularly dry pre-monsoon period in 2006 and relatively wet premonsoon period in 2007 (Fig. 1b, and Shim et al., 2011). The mid-summer monsoon seasons (typically July and August) were characterized by frequent rainfall events and subsequently dynamic SWC (Fig. 1). Again, there was substantial interannual variation, with relatively strong monsoon precipitation in 2006 characterized by an early onset of monsoon rains and particularly short ( $<5$ days) inter-pulse duration (Table A1). 2007 was the driest monsoon season of the four years, with lowest SWC, highest VPD and $T_{\text {soil }}$, and longest inter-pulse durations. $P-E_{\mathrm{P}}$ declined rapidly after pulse events and was particularly low in 2007 and 2008. As a reminder, $P-E_{\mathrm{P}}$ here in Fig. $1 \mathrm{~b}$ was calculated on a daily time step, and in Fig. 8b the daily value was averaged over the period extending from one rain event to the day before the next rain event, never extending more than 11 days. Postmonsoon periods were relatively similar between years and were characterized by decreasing rainfall and declining $T_{\text {soil }}$.

Pre-dawn leaf water potential $\left(\Psi_{\mathrm{pd}}\right)$ tended to track SWC at $20 \mathrm{~cm}$ depth, with least negative values in spring, most 


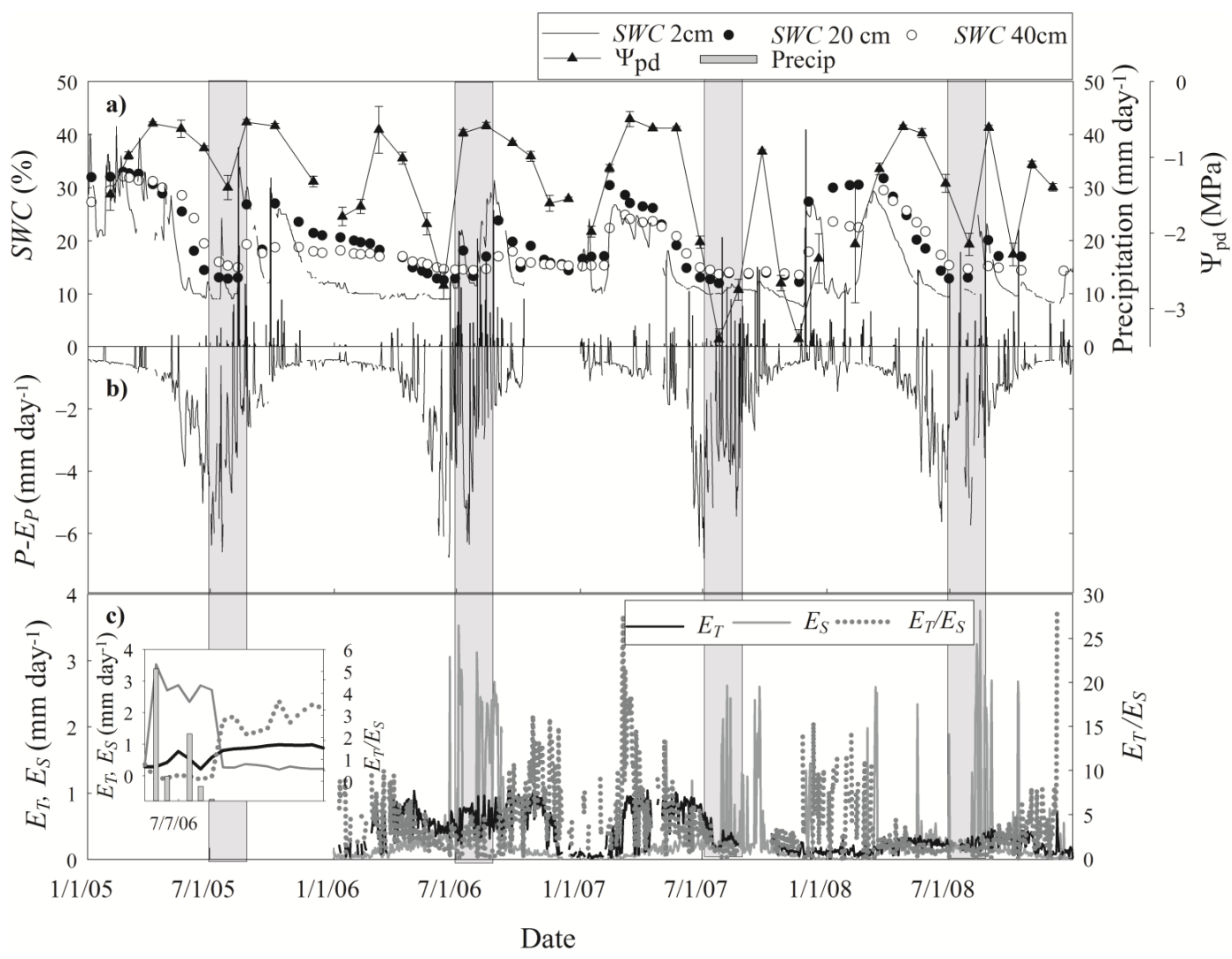

Fig. 1. (a) Time series of precipitation (bars), daily SWC at $2 \mathrm{~cm}$ (lines), and biweekly SWC at $20 \mathrm{~cm}$ (circles). (b) Time series of the drought index $P-E_{\mathrm{P}}$ (grayed area) and its percentiles (gray line). (c) Time series of modeled soil evaporation ( $E_{\mathrm{S}}$ ) from ISOLSM (solid line), canopy transpiration $\left(E_{\mathrm{T}}\right)$ (dashed line), and the $E_{\mathrm{T}} / E_{\mathrm{S}}$ ratio. We include winter time periods because winter precipitation and soil water content could affect the water cycle during pre-monsoon periods ( $\sim$ April to June). Typical post-pulse patterns of $E_{\mathrm{S}}, E_{\mathrm{T}}$, and $E_{\mathrm{T}} / E_{\mathrm{S}}$ are displayed as an inset in (c).

negative values in August, and rebounded in early September (Fig. 1a; $p<0.001, r^{2}=0.3$ ). SWC at $20 \mathrm{~cm}$ depth followed seasonal variation in $P-E_{\mathrm{P}}$ (Fig. $1 \mathrm{~b} ; p<0.001, r^{2}=0.3$ ).

Mean daily $E_{\mathrm{T}}\left(\mathrm{mm} \mathrm{d}^{-1}\right)$ from days 100 to 304 were $0.7 \pm 0.1,0.5 \pm 0.1$, and $0.3 \pm 0.1$ in 2006, 2007 and 2008, respectively. $E_{\mathrm{T}}$ increased after rainfall events throughout the three years of sapflow measurements (Fig. 1c). Average maximum changes in $E_{\mathrm{T}}\left(\mathrm{mm} \mathrm{d}^{-1}\right)$ after pulses were $0.6 \pm 0.2,0.4 \pm 0.1$ and $0.4 \pm 0.2$ during pre-monsoon, monsoon, and post-monsoon periods, respectively. $E_{\mathrm{T}}$ did not exceed $0.3 \mathrm{~mm} \mathrm{day}^{-1}$ when $\Psi_{\mathrm{pd}}$ was $\leq-1 \mathrm{MPa}$ in monsoon and post-monsoon seasons, but did reach higher values for the same $\Psi_{\text {pd }}$ during the pre-monsoon seasons (Fig. A1); this is consistent with the relatively anisohydric behavior of juniper trees (McDowell et al., 2008a). Similarly, $E_{\mathrm{T}}$ responses to VPD were only strong when SWC $\geq 15 \%$, with relatively shallow responses when soil moisture was low (i.e., $<15 \%$; Fig. 3a).

Modeled $E_{\mathrm{S}}$ generally showed rapid spikes and subsequent gradual decreases after rainfall events (inset in Fig. 1c). As $E_{\mathrm{S}}$ declined, $E_{\mathrm{T}}$ consistently increased, resulting in in- creasing $E_{\mathrm{T}} / E_{\mathrm{S}}$ (Fig. 1c, $59 \%$ of rain events) because soil evaporation responds rapidly to pulses, while the vegetation response was more gradual and long-lived because it takes longer for water to infiltrate, reach the rooting zone, transport through xylem, and transpire through the leaves (Reynolds et al., 2004). Strong positive responses of $E_{\mathrm{T}}$ to VPD became evident when SWC $>15 \%$ (Fig. 3a). Average maximum changes in $E_{\mathrm{T}} / E_{\mathrm{S}}$ after pulses were $4.3 \pm 1.3,1.4 \pm 0.4$ and $5.5 \pm 2.5$ during pre-monsoon, monsoon, and post-monsoon periods, respectively. $E_{\mathrm{T}} / E_{\mathrm{S}}$ peaks were associated with elevated soil moisture after snowmelt and during relatively wet monsoon periods due to high values of $E_{\mathrm{T}}$ (Fig. 1a and c, Table A1.).

After filtering atmospheric $\mathrm{CO}_{2} \delta^{18} \mathrm{O}\left(\delta_{\mathrm{a}}\right)$ by our QC (Quality Control) criteria, 64\% of the nights were retained for $\delta_{R}$ calculation from April 2005 through October 2008 (547 nights). Nightly measured $\delta_{\mathrm{R}}$ averaged $46.7 \% \circ \pm 0.6,50.7 \% \circ \pm 0.7,52.6 \% \circ \pm 1.2$, and $44.8 \% \circ \pm 2.3$ in $2005,2006,2007$, and 2008 , respectively. $\delta_{\mathrm{R}}$ generally became depleted immediately after rainfalls and subsequently enriched until the next rain event (Fig. 2). Average maximum 


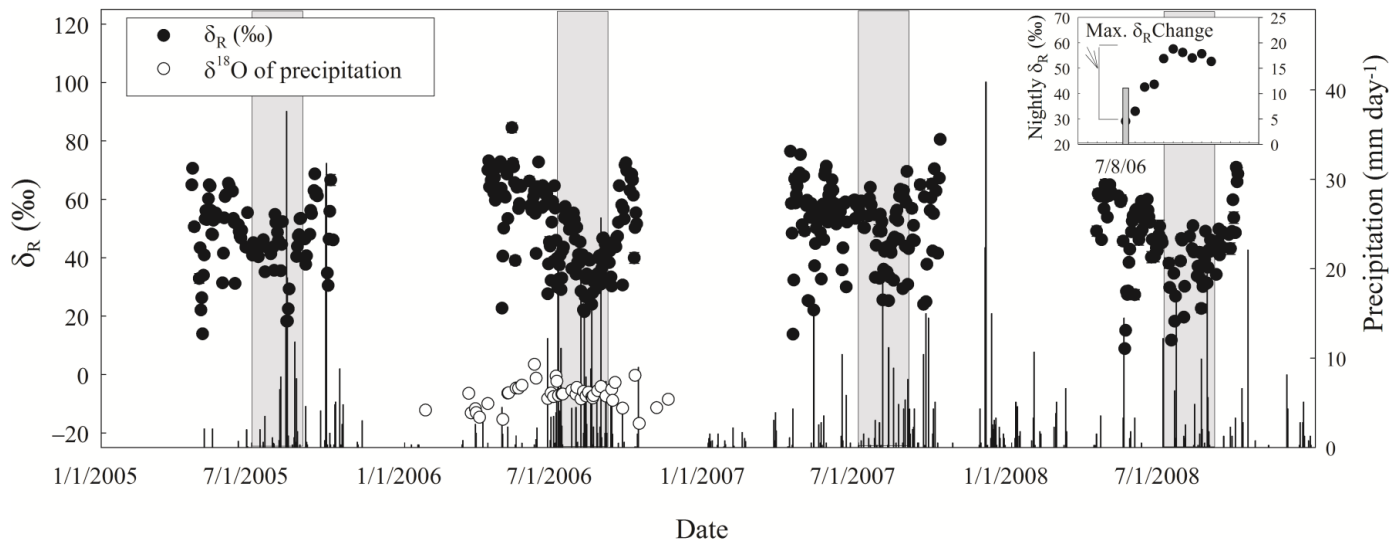

Fig. 2. Annual and seasonal variation in $\delta_{\mathrm{R}}$ over four years. Precipitation is also shown to facilitate visualization. $\delta^{18} \mathrm{O}$ of precipitation (open circle) for year 2006 is included. Filled boxes represent monsoon periods. An approach to calculate maximum $\delta_{\mathrm{R}}$ change is visualized as an inset.

Table 1. $\delta^{18} \mathrm{O}$ values of leaf water, stem water and soil water in 2005 and 2006 . Alphabetic superscripts (a, b, and c) within columns indicate differences among the three groups using Tukey's test $(F=225.1, p<0.001)$. Different soil depths are denoted as ${ }^{\mathrm{d}} 2 \mathrm{~cm},{ }^{\mathrm{e}} 5 \mathrm{~cm},{ }^{\mathrm{f}} 7 \mathrm{~cm},{ }^{\mathrm{g}}$ $10 \mathrm{~cm}$, and ${ }^{\mathrm{h}} 15 \mathrm{~cm}$.

\begin{tabular}{lcccc}
\hline DOY/Year & Day(s) after rain & \multicolumn{3}{c}{18 O $($ SMOW, $\%)$} \\
\cline { 3 - 5 } & & 21.3 & -11.4 & Soils $^{\mathrm{c}}$ \\
\cline { 3 - 5 } $111 / 2005$ & 6 & 18.2 & -12.2 & $-10.5^{\mathrm{d}}$ \\
$137 / 2005$ & 2 & 15.2 & -12.8 & $-8.9^{\mathrm{f}}$ \\
$152 / 2005$ & 18 & 25.3 & -10.7 & $-3.2^{\mathrm{d}},-11.3^{\mathrm{f}}$ \\
$180 / 2005$ & 3 & 20.8 & -10.1 & $-1.1^{\mathrm{g}}$ \\
$184 / 2005$ & 7 & 16.4 & -8.1 & $-5.6^{\mathrm{g}}$ \\
$207 / 2005$ & 8 & 9.6 & -9.2 & $1.4^{\mathrm{g}}$ \\
$208 / 2005$ & 0 & 16.9 & -6.7 & \\
$223 / 2005$ & 5 & & & $-1.5^{\mathrm{d}}, 3.7^{\mathrm{e}}, 2.6^{\mathrm{f}}, 2.5^{\mathrm{g}}, 0.6^{\mathrm{h}}$ \\
$151 / 2006$ & 9 & 23.3 & -6.9 & $-1.8^{\mathrm{g}}$ \\
$167 / 2006$ & 7 & 17.6 & -6.6 & $-1.4^{\mathrm{g}}$ \\
$181 / 2006$ & 1 & 26.7 & -4 & $-2.2^{\mathrm{f}}$ \\
$195 / 2006$ & 4 & 13.9 & -7.2 & $-8.4^{\mathrm{g}}$ \\
$214 / 2006$ & 1 & 14.6 & -7.5 & $-4.3^{\mathrm{g}}$ \\
$223 / 2006$ & 1 & 16.5 & -7.6 & $-2.4^{\mathrm{f}}$ \\
$240 / 2006$ & 2 & 15.1 & -8.4 & $-2.2^{\mathrm{f}} \pm 1.0$ \\
$271 / 2006$ & 6 & 10.5 & -10.2 & \\
$292 / 2006$ & 4 & $17.6 \pm 1.2$ & $-8.7 \pm 0.6$ & \\
Mean \pm SE & $4.9 \pm 1.1$ & & &
\end{tabular}

$\delta_{\mathrm{R}}$ enrichment after pulses was $28.7,18.9$, and $25.6 \%$ during pre-monsoon, monsoon and post-monsoon periods, respectively.

\subsection{Patterns of water pool $\delta^{18} \mathrm{O}$ and relationships of $\delta_{\mathrm{R}}$ and hydrologic drivers after pulses}

Juniper foliage water consistently had the highest $\delta^{18} \mathrm{O}$ values (mean $17.6 \pm 0.2 \%$ ), followed by soil water (mean $-2.2 \pm 1.0 \%$ o $)$ and juniper stem water $(-8.7 \pm 0.6 \%$ o $)$ (Tukey's test, $F=225.1, p<0.001$, Table 1). Foliar water $\delta^{18} \mathrm{O}$ value was positively correlated with VPD $\left(r^{2}=0.7\right.$, $p<0.001)$, but there was no correlation of mean $0-15 \mathrm{~cm}$ soil water $\delta^{18} \mathrm{O}$ value with VPD (Fig. 2b).

$\delta_{\mathrm{R}}$ showed progressive enrichments with increasing VPD and $E_{\mathrm{T}}$ and decreasing $\mathrm{RH}$ at the intraseasonal scale (Table 2 and Fig. A2), indicating the importance of evaporative demand and transpiration on $\delta_{\mathrm{R}}$. Despite the clear dependence of $\delta_{\mathrm{R}}$ on these drought-related parameters, there were no significant relationships between $\delta_{\mathrm{R}}$ and $P-E_{\mathrm{P}}$ when including all nights from DOY 100-273 over the four years (Fig. A3), though a clear pattern emerges of a wide $\delta_{\mathrm{R}}$ range 

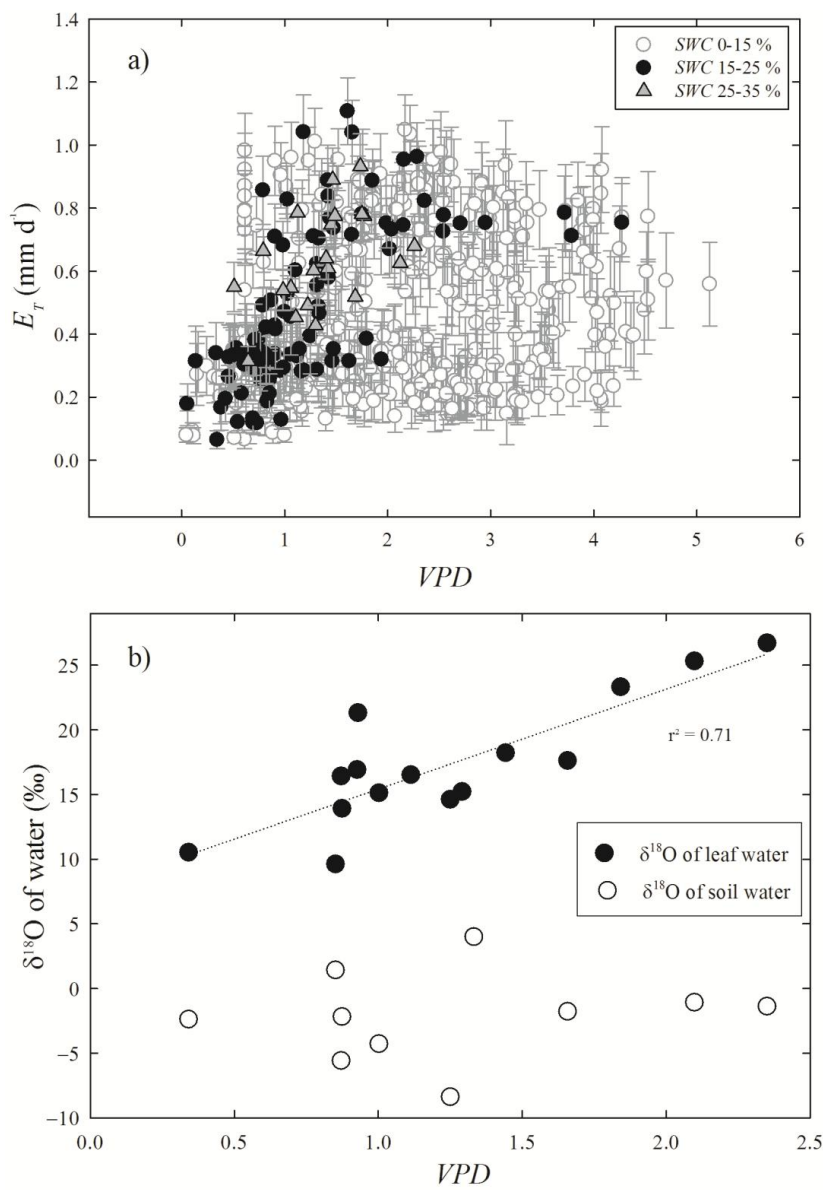

Fig. 3. (a) The interannual and seasonal $E_{\mathrm{T}}-\mathrm{VPD}$ relationships for three sets of SWC, $0-15 \%, 15-25 \%$, and $25-35 \%$. (b) Correlations of foliar and soil water $\delta^{18} \mathrm{O}$ values at $10 \mathrm{~cm}$ depth with VPD for year 2005 and 2006. The foliar regression equation is $\delta^{18} \mathrm{O}=7.7$ $+7.7 \mathrm{VPD}, r^{2}=0.7$. Soil water $\delta^{18} \mathrm{O}$ value was not significantly correlated with VPD.

during wetter periods and a limited range during drought. Thus, $P-E_{\mathrm{P}}$ by itself was not a good predictor of $\delta_{\mathrm{R}}$, perhaps due to the variable $\delta^{18} \mathrm{O}$ of rainfall events. $\delta_{\mathrm{R}}$ on the day of rain events followed annual $\delta^{18} \mathrm{O}$ precipitation trends $\left(r^{2}=0.4, p=0.001\right)$. Indeed, pulse events induced an immediate decrease in $\delta_{\mathrm{R}}$ (Fig. 4b). Following these immediate depletions, $\delta_{\mathrm{R}}$ subsequently became enriched following nearly all pulse events (Fig. 4c). Similarly, $E_{\mathrm{T}}$ increased following rain events (Fig. 4a). The post-pulse $\delta_{\mathrm{R}}$ enrichment typically reached a plateau within five days after the rain event (Fig. 5a-c). The largest and smallest enrichments occurred in pre-monsoon and monsoon seasons, respectively (Fig. 5a-c). The normalized $\delta_{\mathrm{R}}$ enrichment was correlated with $E_{\mathrm{T}}$ (Fig. $\left.5 \mathrm{~d}-\mathrm{f}\right)$.

The model accurately captured the temporal $\delta_{\mathrm{R}}$ dynamics of the post-pulse $\delta_{\mathrm{R}}$ enrichment $\left(r^{2}=0.7\right.$; Fig. 6). Simulated depletion in $\delta_{\mathrm{R}}$ immediately following precipitation events was often underestimated (mean underestimate of

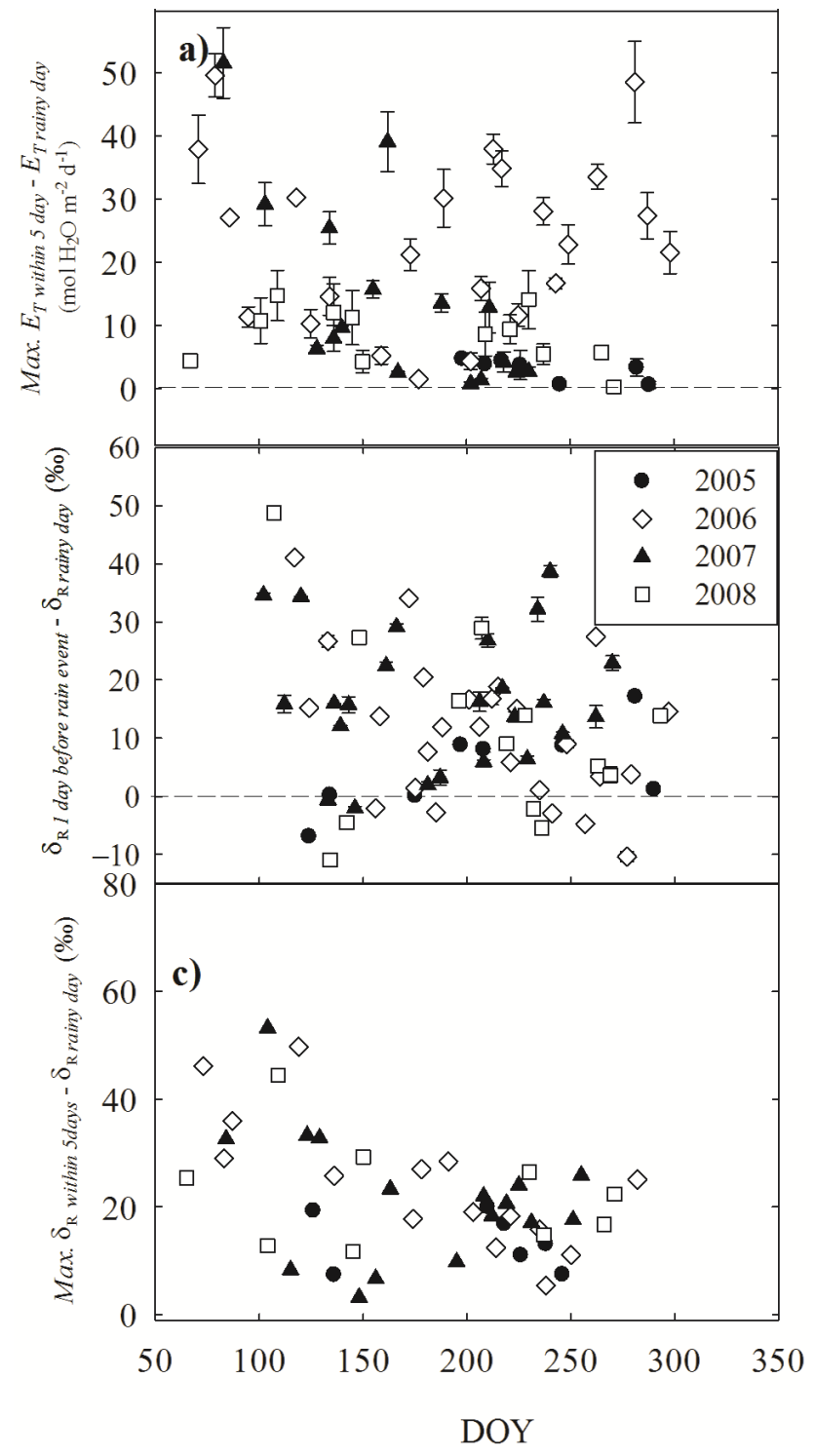

Fig. 4. (a) The differences in $E_{\mathrm{T}}$ between the day of a rain event and the maximum value over the subsequent five days. Positive values indicate $E_{\mathrm{T}}$ was higher after the rain event than before. All rain events were included from DOY 60 to 300. (b) The difference in $\delta_{\mathrm{R}}$ between 1 day before a rain event and $\delta_{\mathrm{R}}$ on the rainy day, shown for 2005-2008. Positive values indicate $\delta_{R}$ values become more depleted by the rain event. (c) The difference in normalized $\delta_{\mathrm{R}}$ between the night of a rain event and the maximum value over the subsequent five nights. $\delta_{\mathrm{R}}$ values were normalized by the day zero $\delta_{\mathrm{R}}$ after a rain event to make all starting values zero over the four years, thereby allowing examination of the response to the rain event. The maximum normalized $\delta_{\mathrm{R}}$ values within 5 days after pulse events typically captured the maximum enrichment (Fig. 5a-c).

$7.2 \pm 1.6 \%$; Fig. A7). The $\delta_{\mathrm{R}}$ prediction accuracy improved greatly after the one-way flux model proposed by Cernusak et al. (2004) was incorporated to estimate leaf $\mathrm{C}^{18} \mathrm{OO}$ fluxes $\left(p<0.001\right.$ for all, $r^{2}=0.2$ and 0.5 for net flux model and 


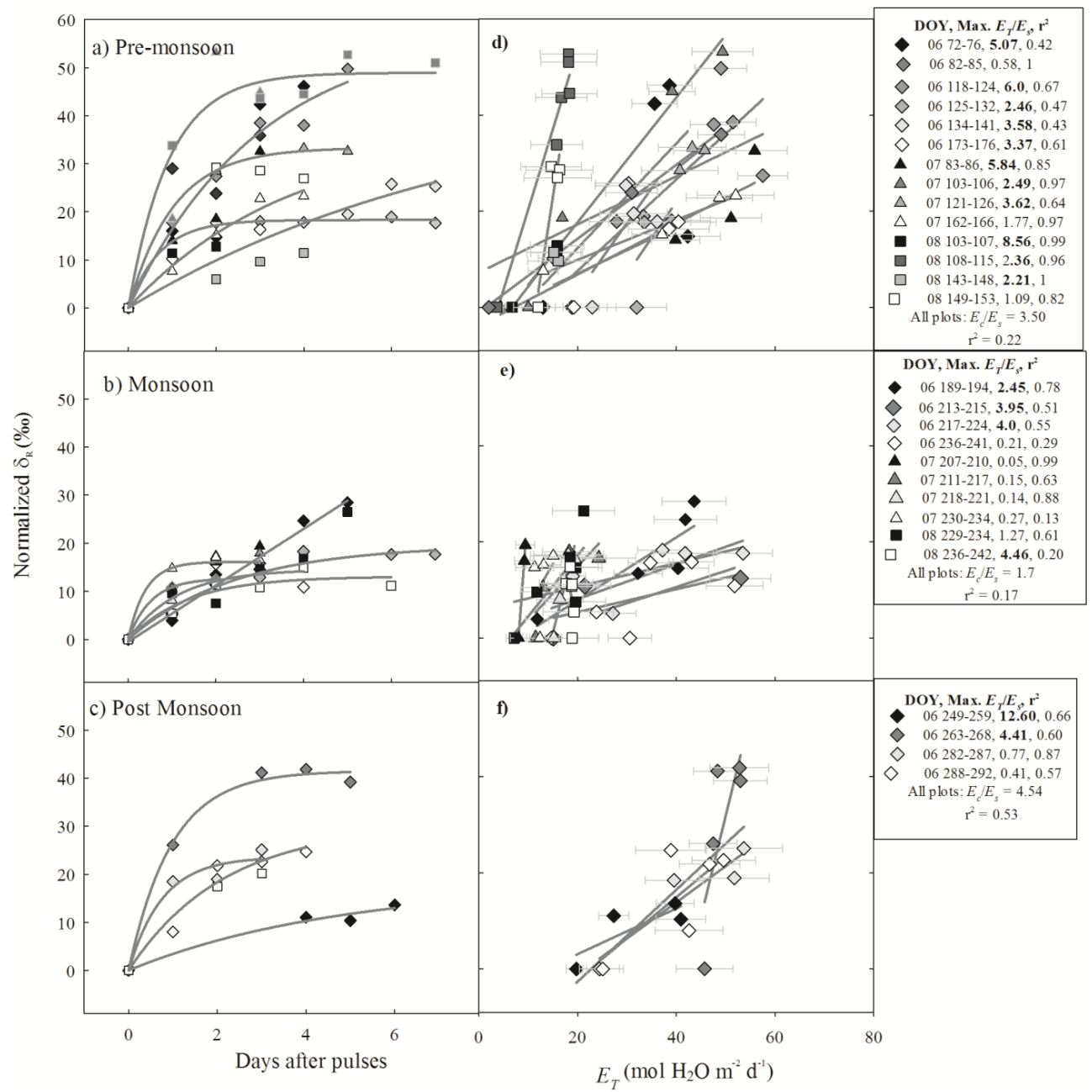

Fig. 5. (a-c) Seasonal patterns of normalized $\delta_{R}$ enrichment after rain pulses (the pulses are on day zero). $\delta_{R}$ values were normalized by $\delta_{R}$ on the day of the rain event to make all starting values zero over the four years. (d-f) The seasonal relationships between post-rain-pulse normalized $\delta_{\mathrm{R}}$ and $E_{\mathrm{T}}$. Maximum $E_{\mathrm{T}} / E_{\mathrm{S}}$ values and $r^{2}$ values for the same period are added in each legend. Maximum $E_{\mathrm{T}} / E_{\mathrm{S}}>2$ is expressed as bold.

one-way flux model, respectively; Fig. A4). The higher accuracy of the one-way flux model is consistent with large enrichment of chloroplast $\mathrm{CO}_{2}$. ISOLSM predicted that foliar $\mathrm{C}^{18} \mathrm{OO}$ flux was the dominant contributor to post-pulse $\delta_{\mathrm{R}}$ enrichment during pre- and post-monsoon periods over the three years, whereas soil $\mathrm{C}^{18} \mathrm{OO}$ flux was the dominant contributor during monsoon periods (Fig. 7).

Consistent with our expectations, $\delta_{\mathrm{R}}$ enrichment was correlated with $E_{\mathrm{T}} / E_{\mathrm{S}}$ (Fig. 8a). A stronger relationship between $\delta_{\mathrm{R}}$ and $P-E_{\mathrm{P}}$ emerged after accounting for precipitation effects on ecosystem water pools by calculating the maximum $\delta_{\mathrm{R}}$ change between the day of the rain event and the subsequent dry period (see methods, $r^{2}=0.4$, $p=0.001$, Fig. 8 b). This also highlights that increasing precipitation and decreasing potential evapotranspiration both lead to larger enrichment of $\delta_{\mathrm{R}}$ after rain events.

\section{Discussion}

$\delta_{\mathrm{R}}$ did not simply increase with larger values of $P-E_{\mathrm{P}}$ (Fig. A3). Rather, the relationship between $\delta_{\mathrm{R}}$ and $P-E_{\mathrm{P}}$ was heavily moderated by precipitation events (Fig. 8b). Further, the four-year semi-continuous $\delta_{\mathrm{R}}$ observations exhibited strong coupling of $\delta_{\mathrm{R}}$ with hydrological attributes of local weather $\left(P-E_{\mathrm{P}}, \mathrm{VPD}\right.$, and $\left.\mathrm{RH}\right)$ and ecosystem physiology ( $E_{\mathrm{T}}$ and $\left.E_{\mathrm{T}} / E_{\mathrm{S}}\right)$ at daily (Figs. 3, 5, Fig. A2), seasonal (Fig. 5, Fig. A2) and interannual scales (Figs. 3, 5, Fig. A2). The wide $\delta_{\mathrm{R}}$ range at more positive $P-E_{\mathrm{P}}$ and narrow range at more negative $P-E_{\mathrm{P}}$ (Fig. A3) appears to be the result of multiple factors, most notably resetting of water pool $\delta^{18} \mathrm{O}$ values by rain (Fig. 5b), and regulation of subsequent enrichment by transpiration and soil evaporation (Figs. 1, 2, 5, 8). The magnitude of post-pulse $\delta_{\mathrm{R}}$ enrichment varied with seasonal and interannual climate (Figs. 1, 5) due 
Table 2. Correlation coefficients $\left(r^{2}\right)$ of $\delta_{\mathrm{R}}$ with VPD, SWC, RH, and $E_{\mathrm{T}}$ for each pulse event. The number of days lagged is presented along with the sign of relationship in parentheses. ${ }^{\mathrm{a}}$ Regression significance: $p \leq 0.1 .{ }^{\mathrm{b}}$ Regression significance: $p \leq 0.05$. Blanks: data not available. Horizontal dashed lines indicate season shifts between pre-monsoon, monsoon, and post-monsoon.

\begin{tabular}{|c|c|c|c|c|c|}
\hline Day of year & VPD & SWC_2 cm & RH & $E_{\mathrm{T}}$ & Pulse size $(\mathrm{mm})$ \\
\hline \multicolumn{6}{|l|}{ Pre-monsoon } \\
\hline $125-132(2005)$ & $0.33(0,+)^{\mathrm{a}}$ & $0.81(0,-)^{b}$ & $0.87(0,-)^{b}$ & & 2.1 \\
\hline $135-143$ (2005) & $0.71(0,+)^{b}$ & $0.53(0,-)^{\mathrm{a}}$ & $0.79(0,-)^{b}$ & & 2.1 \\
\hline \multicolumn{6}{|l|}{ Monsoon } \\
\hline 198-206 (2005) & $0.36(0,+)$ & $0.5(0,-)$ & $0.67(0,-)$ & & 3.5 \\
\hline $207-213(2005)$ & $0.5(0,+)^{\mathrm{a}}$ & $0.43(0,-)$ & $0.45(0,-)^{a}$ & & 2 \\
\hline $234-244(2005)$ & $0.27(0,+)$ & $0.71(0,-)^{\mathrm{b}}$ & $0.51(0,-)^{\mathrm{a}}$ & & 21.9 \\
\hline \multicolumn{6}{|l|}{ Post-monsoon } \\
\hline $245-253(2005)$ & $0.83(1,+)^{b}$ & $0.81(0,-)^{b}$ & $0.9(1,-)^{b}$ & & 9.4 \\
\hline $271-278(2005)$ & $\sim 0(0,-)$ & $0.78(0,-)^{b}$ & $0.05(0,+)$ & $0.63(0,-)$ & 61.7 \\
\hline $282-287$ (2005) & $0.94(0,+)^{b}$ & $0.02(0,-)$ & $0.94(0,-)^{b}$ & $0.36(0,+)$ & 9.9 \\
\hline \multicolumn{6}{|l|}{ Pre-monsoon } \\
\hline $118-123(2006)$ & $0.86(1,+)^{b}$ & $0.52(1,+)^{\mathrm{a}}$ & $0.83(1,-)^{b}$ & $0.69(1,+)^{b}$ & 6 \\
\hline $125-131(2006)$ & $0.69(2,+)^{\mathrm{a}}$ & $0.93(0,-)^{b}$ & $0.43(2,-)$ & $0.53(0,+)$ & 2.3 \\
\hline $135-141(2006)$ & $0.86(2,+)^{\mathrm{a}}$ & $0.98(4,-)^{\mathrm{a}}$ & $0.89(3,-)^{\mathrm{a}}$ & $0.95(4,+)^{\mathrm{a}}$ & 1.6 \\
\hline $160-167$ (2006) & $0.39(3,-)$ & & $0.76(2,+)^{\mathrm{a}}$ & $0.73(1,+)^{\mathrm{a}}$ & 2.2 \\
\hline 173-178 (2006) & $0.06(0,+)$ & $0.53(0,+)$ & $0.14(1,+)$ & $0.44(0,+)$ & 16.4 \\
\hline \multicolumn{6}{|l|}{ Monsoon } \\
\hline 184-191 (2006) & $0.34(0,+)^{\mathrm{a}}$ & $\sim 0(0,+)$ & $0.38(0,-)^{\mathrm{a}}$ & $0.34(0,+)^{\mathrm{a}}$ & 29.1 \\
\hline $217-222(2006)$ & $0.74(0,+)^{b}$ & $0.72(0,+)^{b}$ & $0.73(0,-)^{b}$ & $0.42(0,+)$ & 31 \\
\hline $225-230(2006)$ & $0.07(0,+)$ & $0.75(0,+)^{\mathrm{a}}$ & $0.07(0,-)$ & $\sim(0,-)$ & 28.3 \\
\hline $231-235$ (2006) & $0.82(0,+)^{\mathrm{a}}$ & $0.1(0,+)$ & $0.76(0,-)^{a}$ & $0.03(0,+)$ & 16.8 \\
\hline $236-241(2006)$ & $0.98(0,+)^{b}$ & $\sim 0(0,+)$ & $0.98(0,-)^{b}$ & $0.27(0,+)$ & 29.1 \\
\hline 243-248 (2006) & $0.23(0,+)$ & $0.06(0,+)$ & $0.22(0,-)$ & $0.01(0,+)$ & 10.6 \\
\hline \multicolumn{6}{|l|}{ Post-monsoon } \\
\hline $249-255$ (2006) & $0.88(1,+)^{\mathrm{a}}$ & $0.86(3,-)^{b}$ & $0.99(1,-)^{b}$ & $0.69(4,+)^{\mathrm{a}}$ & 13.4 \\
\hline $254-259$ (2006) & $0.73(0,+)^{b}$ & $0.83(0,-)^{b}$ & $0.92(0,-)^{b}$ & $0.41(0,+)$ & 1 \\
\hline $282-286(2006)$ & $0.95(0,+)^{b}$ & $0.83(0,+)^{\mathrm{a}}$ & $0.96(0,-)^{b}$ & $\mathbf{0 . 8 7}(0,+)^{\mathrm{a}}$ & 9 \\
\hline \multicolumn{6}{|l|}{ Pre-monsoon } \\
\hline $103-106$ (2007) & $0.94(0,+)^{b}$ & $0.57(0,+)$ & $0.93(0,-)^{b}$ & $0.97(0,+)^{b}$ & 4.3 \\
\hline $128-133$ (2007) & $0.82(0,+)^{b}$ & $0.62(0,+)^{\mathrm{a}}$ & $0.75(0,-)^{b}$ & $0.22(0,-)$ & 16.3 \\
\hline $134-140(2007)$ & $0.54(0,+)^{\mathrm{a}}$ & $0.74(3,-)^{b}$ & $0.54(0,-)^{\mathrm{a}}$ & $0.19(0,-)$ & 9.6 \\
\hline $140-150$ (2007) & $0.17(3,-)$ & $0.24(1,+)^{\mathrm{a}}$ & $0.67(3,+)$ & $0.16(3,-)$ & 8.6 \\
\hline $162-166$ (2007) & $0.4(0,+)$ & $0.89(0,+)^{\mathrm{a}}$ & $0.34(0,-)$ & $0.17(0,+)$ & 11.2 \\
\hline \multicolumn{6}{|l|}{ Monsoon } \\
\hline 200-206 (2007) & $0.19(0,+)$ & $0.62(0,+)$ & $0.26(0,-)$ & $0.5(0,+)$ & 6 \\
\hline $211-216(2007)$ & $0.87(0,+)^{b}$ & $0.25(0,+)$ & $0.71(0,-)^{\mathrm{a}}$ & $0.6(0,+)^{\mathrm{a}}$ & 20.6 \\
\hline $218-223$ (2007) & $0.73(0,+)^{b}$ & $0.67(0,+)^{\mathrm{a}}$ & $0.75(0,-)^{b}$ & $0.47(0,+)^{\mathrm{a}}$ & 11.2 \\
\hline $224-229(2007)$ & $0.85(0,+)^{b}$ & $\sim 0(0,+)$ & $0.92(0,-)^{b}$ & $0.22(0,-)$ & 8.9 \\
\hline 230-234 (2007) & $0.79(0,+)^{b}$ & $0.28(0,-)$ & $0.78(0,-)^{\mathrm{a}}$ & $0.08(0,+)$ & 4.8 \\
\hline $236-240(2007)$ & $0.07(0,+)$ & $0.05(0,-)$ & $0.08(0,-)$ & & 9.6 \\
\hline $241-246$ (2007) & $0.4(0,+)$ & $0.41(2,-)$ & $0.41(2,+)$ & & 22.1 \\
\hline \multicolumn{6}{|l|}{ Post-monsoon } \\
\hline $247-254$ (2007) & $0.8(2,-)^{b}$ & $0.55(3,+)$ & $0.6(2,+)^{\mathrm{a}}$ & & 8.6 \\
\hline $260-266$ (2007) & $0.36(2,-)$ & $0.88(4,+)^{\mathrm{a}}$ & $0.3(0,-)$ & & 40.1 \\
\hline $271-276(2007)$ & $0.84(1,-)^{\mathrm{a}}$ & $\mathbf{0 . 8}(0,-)^{\mathrm{a}}$ & $0.61(1,+)$ & & 10.9 \\
\hline
\end{tabular}


Table 2. Continued.

\begin{tabular}{|c|c|c|c|c|c|}
\hline Day of year & VPD & $\mathrm{SWC} \_2 \mathrm{~cm}$ & RH & $E_{\mathrm{T}}$ & Pulse size (mm) \\
\hline \multicolumn{6}{|l|}{ Pre-monsoon } \\
\hline $107-114$ (2008) & $0.66(0,+)^{b}$ & $0.6(0,-)^{b}$ & $0.4(0,+)$ & $0.94(0,+)^{b}$ & 3.5 \\
\hline $134-140$ (2008) & $0.64(2,+)^{\mathrm{a}}$ & $0.76(0,-)^{\mathrm{a}}$ & $0.29(1,-)$ & $0.66(3,+)^{b}$ & 4.8 \\
\hline $142-147(2008)$ & $0.1(0,+)$ & $0.86(0,-)^{b}$ & $0.13(0,+)$ & $0.7(0,+)^{\mathrm{a}}$ & 2.8 \\
\hline $148-155(2008)$ & $\sim 0(0,+)$ & $0.09(0,-)$ & $0.03(0,+)$ & $0.64(0,+)^{b}$ & 3.3 \\
\hline $235-241$ (2008) & $0.06(1,+)$ & $0.75(1,+)^{\mathrm{a}}$ & $0.59(1,-)^{\mathrm{a}}$ & $0.20(0,-)$ & 28.2 \\
\hline \multicolumn{6}{|l|}{ Monsoon } \\
\hline $197-206$ (2008) & $0.46(0,+)$ & $0.69(0,+)$ & $0.04(0,+)$ & $0.93(0,-)^{b}$ & 21.8 \\
\hline $207-215$ (2008) & $0.46(0,+)$ & $0.85(0,-)^{\mathrm{a}}$ & $0.42(0,+)$ & $0.13(0,+)$ & 4.8 \\
\hline $216-225$ (2008) & $0.03(0,-)$ & $0.70(0,-)^{\mathrm{a}}$ & $0.02(0,+)$ & $0.46(0,-)$ & 50.5 \\
\hline $222-229$ (2008) & $0.48(5,-)^{\mathrm{a}}$ & $0.27(4,-)$ & $0.42(3,-)^{\mathrm{a}}$ & $0.62(0,+)^{a}$ & 38.4 \\
\hline $228-234(2008)$ & $0.03(0,-)$ & $0.87(0,-)^{b}$ & $0.62(0,+)^{\mathrm{a}}$ & $0.61(0,+)^{\mathrm{a}}$ & 12.5 \\
\hline 235-241 (2008) & $0.06(1,+)$ & $0.75(1,+)^{\mathrm{a}}$ & $0.59(1,-)^{\mathrm{a}}$ & $0.20(0,-)$ & 28.2 \\
\hline \multicolumn{6}{|l|}{ Post-monsoon } \\
\hline $243-251$ (2008) & $0.46(4,+)^{\mathrm{a}}$ & $0.22(2,-)$ & $0.18(4,-)$ & $0.74(0,+)^{\mathrm{a}}$ & 22 \\
\hline $263-268$ (2008) & $0.01(0,-)$ & $0.32(0,-)$ & $0.07(0,+)$ & $0.01(0,+)$ & 3.6 \\
\hline 269-274 (2008) & $0.13(0,-)$ & $0.28(0,-)$ & $0.16(0,+)$ & $0.11(0,-)$ & 3.3 \\
\hline 284-293(2008) & $0.79(0,+)^{\mathrm{a}}$ & $0.89(0,+)^{\mathrm{a}}$ & $0.86(0,-)^{\mathrm{a}}$ & $0.62(0,+)$ & 28.7 \\
\hline
\end{tabular}

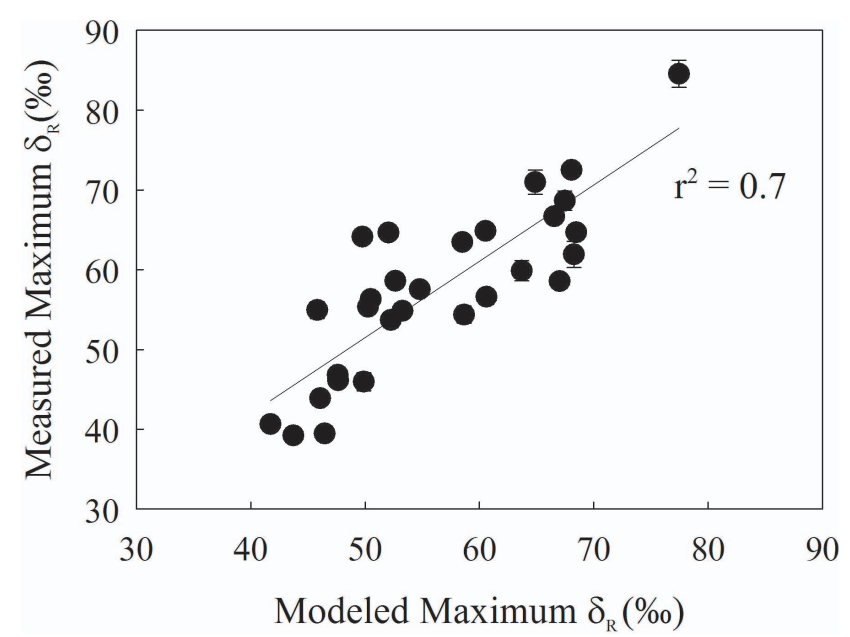

Fig. 6. Comparison between measured and modeled maximum $\delta_{R}$ changes within 7 days of precipitation.

in part to constraints on the $E_{\mathrm{T}}$ response (Figs. 1, 2, 4, 8 and Fig. A1) and changes in $E_{\mathrm{T}} / E_{\mathrm{S}}$ (Fig. 8a). These patterns support the contention of strong hydrological regulation of ecosystem function in semi-arid regions (Weltzin and Tissue, 2003) and suggest that long-term monitoring of $\delta_{\mathrm{R}}$ has promise for understanding drought responses and detecting drought induced eco-physiological changes. Below, we explore the potential mechanisms driving the drought signal of $\delta_{\mathrm{R}}$.

Rain reset near-surface soil and source (i.e., xylem water) $\delta^{18} \mathrm{O}$ values, causing immediate $\delta_{\mathrm{R}}$ depletions followed by subsequent enrichment as the ecosystem dried (Figs. 1, 4, 5), consistent with previous results from short-term (i.e., $60 \mathrm{~min}$ utes) post-pulse measurements of the $\delta^{18} \mathrm{O}$ value of soil $\mathrm{CO}_{2}$ effluxes at our site (Powers et al., 2010). ISOLSM was not consistently accurate in simulating $\delta_{\mathrm{R}}$ depletions within hours of the rainfall events, for several reasons. First, comparisons between the available precipitation $\delta^{18} \mathrm{O}$ measurements at the site for the time periods presented in our study in 2006 indicate that the ISOLSM forcing precipitation isotope composition was, on average, $3.1 \%$ more enriched than observed (Fig. A7). Therefore, the imposed $\delta^{18} \mathrm{O}$ value of above-canopy vapor following precipitation would also be too enriched in the simulations (Riley et al., 2002). ISOLSM precipitations were less dynamic than observations, particularly depletions during pulse events. Second, pulse events often trigger a brief large burst of soil $\mathrm{CO}_{2}$ efflux (i.e., the Birch effect (Birch, 1964) in arid and semi-arid ecosystems, which can impact $\delta_{\mathrm{R}}$ for short periods. Modeling the Birch effect is difficult because it cannot be simply formulated using only soil temperature and moisture, as done in ISOLSM and many terrestrial ecosystem models. Despite these caveats, the model simulations are useful because we focus not on the immediate few hours following rainfall but on the multiday responses following rainfall. $93 \%$ of our analysis periods (in which data was used in the results) contained zero rainfall because nearly all rain events occurred during the day from convective storms and the data analysis was for periods starting the subsequent nights after a rain event. ISOLSM captured the measured $\delta_{\mathrm{R}}$ within 7 days of the precipitation $\left(r^{2}=0.7\right.$; Fig. 6) after we (1) imposed a two-hour turnover time to the leaf water pool considering leaf water may be enriched several hours after transpiration ceases due to slow 


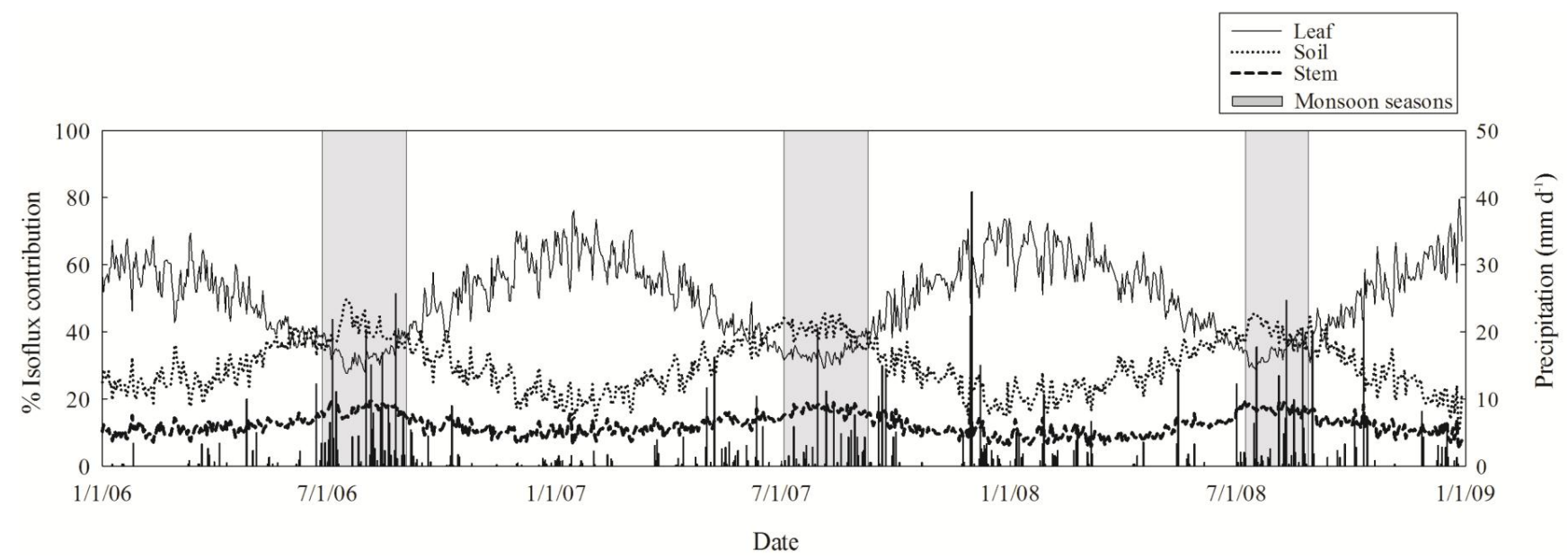

Fig. 7. Time series of foliar, soil, and stem contributions to total ecosystem isoflux derived from ISOLSM. Filled boxes represent monsoon periods.

turnover of the leaf water pool (Cuntz et al., 2003a; Lai et al., 2006) and (2) incorporated a one-way flux model proposed by Cernusak et al. (2004).

Comparison of modeled and observed $\delta_{\mathrm{R}}$ at this site in 2006 demonstrated that nocturnal isotopic equilibration of $\mathrm{CO}_{2}$ with leaf water $\delta^{18} \mathrm{O}$ value and subsequent atmospheric retro-flux may drive large enrichment in $\delta_{\mathrm{R}}$ (McDowell et al., 2008b). The higher accuracy of the one-way flux model is consistent with large enrichment of chloroplast $\mathrm{CO}_{2}(\mathrm{Cer}-$ nusak et al., 2004). This one-way flux model is similar to $\mathrm{CO}_{2}$ invasion and retro-flux in soils (Tans, 1998; Riley et al., 2005; Seibt et al., 2006). Stomata are assumed to be closed at night in many isotope land models; however, accumulated evidence has shown that stomata are leaky at night in many species (Barbour et al., 2005; Dawson et al., 2007). Limited nocturnal, leaf-level measurements of stomatal conductance $\left(g_{\mathrm{c}}\right)$ confirmed that junipers do maintain some degree of stomatal conductance after sundown (up to $0.11 \mathrm{~mol} \mathrm{~m}^{-2} \mathrm{~s}^{-1}, \mathrm{SE}=0.003$, unpublished data). Markedly improved $\delta_{\mathrm{R}}$ prediction by ISOLSM suggests nocturnal $g_{\mathrm{c}}$ leads to high $\mathrm{CO}_{2}$ retro-diffusion and a faster exchange of leaf water with atmospheric water vapor at night, and the $\delta^{18} \mathrm{O}$ composition of leaf water may not be in equilibrium with xylem water at night (Cernusak et al., 2004; Seibt et al., 2006; Lai et al., 2006; Cuntz et al., 2007).

The $\delta_{\mathrm{R}}$ values over four years of study showed $\delta_{\mathrm{R}}$ enrichment following pulse events in $95 \%$ of the observations (Fig. 2). Correlations of $\delta_{\mathrm{R}}$ with VPD and RH over the subsequent days after pulse events and lasting up to 11 days were stronger than for SWC (Table 2). These relationships suggest that declines in atmospheric vapor content following precipitation pulses were a stronger driver of $\delta_{\mathrm{R}}$ patterns than the availability of soil moisture per se (i.e., water content), consistent with observations from more mesic sites (Bowling et al., 2003a, b; Wingate et al., 2010).
The underlying drivers of the correlations of VPD and RH with $\delta_{\mathrm{R}}$ are likely driven by both soil evaporation and canopy transpiration. The post-pulse normalized $\delta_{\mathrm{R}}$ enrichment correlated strongly with $E_{\mathrm{T}} / E_{\mathrm{S}}$ over the three years from DOY 100 to 273 (Fig. 8a). Post-pulse $\delta_{\mathrm{R}}$ enrichment was relatively small when $E_{\mathrm{T}} / E_{\mathrm{S}}<2$, due in part to $E_{\mathrm{T}}$ constraints and a higher contribution of soil $\mathrm{C}^{18} \mathrm{OO}$ flux to total isoflux (Figs.1, 5 - see legend). Post-pulse $\delta_{\mathrm{R}}$ enrichment was significantly larger when $E_{\mathrm{T}}$ and its relative contribution to ecosystem-scale evapotranspiration were large (Figs. 5, 8a) consistent with leaf-level observations in droughted plants. This $\delta_{\mathrm{R}}$ enrichment was likely a result of the enrichment of foliar water as well as retro-diffusion with atmospheric $\mathrm{CO}_{2}$. With active transpiration, water transpired by foliage is more enriched than soil water (Table 1, Wingate et al., 2010) because evaporation results in more efficient accumulation of heavier water molecules in leaf water than soil water (Table 1, Wang and Yakir, 1995; Barbour et al., 2005; Wingate et al., 2010). In our system, this enrichment resulted in a strong relationship between VPD and foliar water $\delta^{18} \mathrm{O}$ values, but no relationship between VPD and soil water $\delta^{18} \mathrm{O}$ values (Fig. 3b). This more enriched foliar water is likely to persist several hours at night after transpiration ceases, as suggested by ISOLSM.

The post-pulse normalized $\delta_{\mathrm{R}}$ enrichment correlated well with $E_{\mathrm{T}} / E_{\mathrm{S}}$ over the three years from DOY 100 to 273 (Fig. 8a). The magnitudes of post-pulse $E_{\mathrm{T}}$ and $\delta_{\mathrm{R}}$ enrichment were larger and more frequently observed during premonsoon periods than during monsoon periods (Fig. 5). Strong positive responses of $E_{\mathrm{T}}$ to VPD were more common when more soil water was available (Fig. 3a). Strong responses of $E_{\mathrm{T}} / E_{\mathrm{S}}$ to pulses corresponded with high $\Psi_{\mathrm{pd}}$ and lower VPD (not shown). All of these factors were most common pre-monsoon when snowmelt had recharged the entire soil water profile (Fig. 1). The source partitioning analysis 


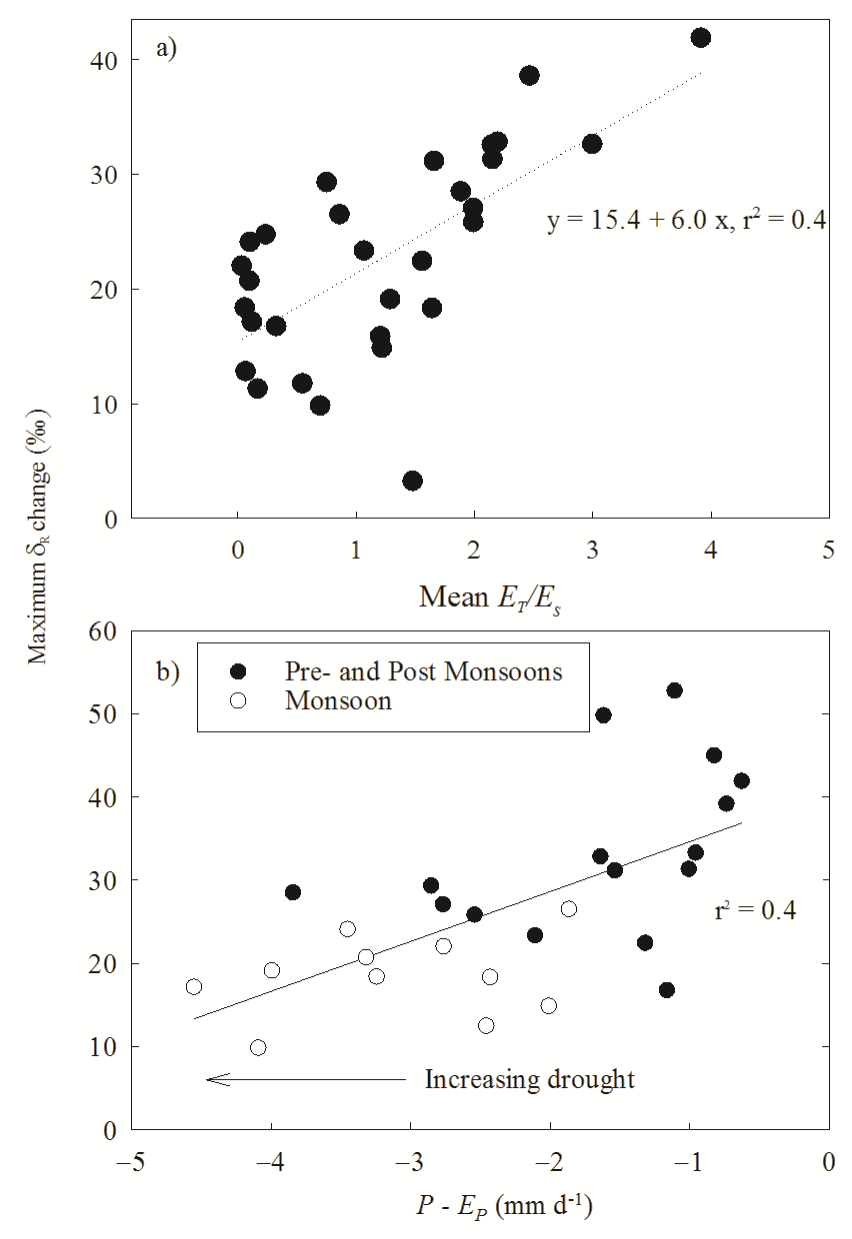

Fig. 8. (a) The relationship between maximum $\delta_{\mathrm{R}}$ change within 7-11 days after each pulse and mean $E_{\mathrm{T}} / E_{\mathrm{S}}$ change for the same periods. The regression equation is $\delta_{\mathrm{R}}=15.4+6.0 E_{\mathrm{T}} / E_{\mathrm{S}}, r^{2}=0.4$. (b) Relationships between maximum $\delta_{\mathrm{R}}$ change and the drought index $P-E_{\mathrm{P}}$. Each data point represents the combination of maximum $\delta_{\mathrm{R}}$ change and mean $P-E_{\mathrm{P}}$ over the same period, with each subset starting on the day of the rain pulse and extending to the day before the next rain pulse.

from ISOLSM provides evidence of higher foliar contribution to total ecosystem isoflux relative to soil and stem components during pre-monsoon periods (Fig. 7). Both $E_{\mathrm{T}}$ and $E_{\mathrm{S}}$ responded strongly to spring rains despite their small size, yet $E_{\mathrm{T}} / E_{\mathrm{S}}$ frequently exceeded 2 because of transient $E_{\mathrm{S}}$ spikes and more sustained increases in $E_{\mathrm{T}}$ (Fig. 1c in inset, Fig. 5 in legend).

Soil isoflux contributed relatively more than leaf isoflux to the ecosystem signal during the monsoon periods (Fig. 7). The monsoon periods typically had more negative $\Psi_{\mathrm{pd}}$, lower soil water content deep in the soil profile (Fig. 1), and higher temperatures, thus only particularly large rain events or many rainy days in a row triggered significant $\delta_{\mathrm{R}}$ responses. $E_{\mathrm{T}}$ increased within a few days after monsoon rains, but the $E_{\mathrm{T}}$ amplitudes were small and post-pulse $E_{\mathrm{T}} / E_{\mathrm{S}}$ usually re- mained below 1.5 (particularly for the dry 2007 and 2008 monsoon seasons, Figs. 1c, 5). The least $\delta_{\mathrm{R}}$ enrichment after rain events was observed during seasons when the postrainfall $E_{\mathrm{T}}$ response was small and the drought index $P-E_{\mathrm{P}}$ was highly negative (Fig. $8 \mathrm{~b}$ ). While $\delta_{\mathrm{R}}$ was strongly related to atmospheric vapor pressure deficit, the degree of enrichment appears constrained by the trees' capacity to increase $E_{\mathrm{T}}$ (Figs. 1, 5e, Fig. A1, Ferrio et al., 2009). However, further manipulative studies that alter VPD and $E_{\mathrm{T}}$ separately are needed to test models of $\delta^{18} \mathrm{O}$ exchange.

Coupling of $\delta_{\mathrm{R}}$ with VPD, RH, and $E_{\mathrm{T}}$ occurred more rapidly, and more frequently, than observed for the $\delta^{13} \mathrm{C}$ value of ecosystem respiration $\left(\delta^{13} C_{R}\right)$ at this ecosystem for the same years (Table 2, Fig. A2, Shim et al., 2011). This more rapid coupling is likely due to the immediate exchange of oxygen atoms between respiring $\mathrm{CO}_{2}$ and water pools, leading to fast incorporation of the water isotopic signature into ecosystem respiration (Wingate et al., 2010). In contrast, $\delta^{13} \mathrm{C}_{\mathrm{R}}$ is derived from the relatively slower transport of carbon from foliage to the mean location of respiration (foliage, stems, roots, and heterotrophic biomass), including additional lags due to autotrophic and heterotrophic storage (Bowling et al., 2008). These storage effects, in particular, make deciphering the information derived from $\delta^{13} C_{R}$ measurements more difficult because $\delta^{13} \mathrm{C}_{\mathrm{R}}$ is frequently uncoupled from climate, at least in this semi-arid woodland (Shim et al., 2011). Thus, the relative value of $\delta_{\mathrm{R}}$ is enhanced not only by its unique representation of terrestrial hydrology, but also because its dependence on climate and physiology is more easily detected.

\section{Conclusions}

In our system, the $\delta^{18} \mathrm{O}$ value of ecosystem respiration $\left(\delta_{\mathrm{R}}\right)$ was highly variable (Fig. 2); this variability was reduced as drought increased $\left(P-E_{\mathrm{P}}\right.$, Fig. A3). Evaporative demand plays a significant role in the $\delta_{\mathrm{R}}$ enrichment following rain events, and this response was strongly influenced by $E_{\mathrm{T}}$ and $E_{\mathrm{T}} / E_{\mathrm{S}}$ (Figs. 5, 8) due in part to strong leaf water enrichment (Fig. 3) and subsequent foliar respiration and retro-diffusion (Figs. 5, Fig. A4). Conditions that limit $E_{\mathrm{T}}$ subsequently limit the $\delta_{\mathrm{R}}$ enrichment post-rain events (Figs. 1, 2, 5, 6), resulting in reduced enrichment when $P-E_{\mathrm{P}}$ is more negative (Fig. 8b). Thus, deciphering the drought signal associated with $\delta_{\mathrm{R}}$ requires consideration of episodic dynamics of precipitation pulses, their impacts on the $\delta^{18} \mathrm{O}$ value of source water pools, and the magnitude of $E_{\mathrm{T}}$ responses. 


\section{Appendix A}

Table A1. Seasonal rain pulse sizes and inter-pulse duration shown as the percentage of events and durations, respectively. The numbers within parentheses are the number of rain events. The maximum days column shows the maximum number of days between pulse events.

\begin{tabular}{|c|c|c|c|c|c|c|c|c|}
\hline \multirow[t]{2}{*}{ Year/season } & \multicolumn{4}{|c|}{ Pulse sizes $(\%)$} & \multicolumn{3}{|c|}{ Inter-pulse durations (\%) } & \multirow{2}{*}{$\begin{array}{c}\text { Maximum } \\
\text { days }\end{array}$} \\
\hline & $1-5 \mathrm{~mm}$ & $5-15 \mathrm{~mm}$ & $15-30 \mathrm{~mm}$ & $>30 \mathrm{~mm}$ & 1 day & $2-5$ days & $>5$ days & \\
\hline \multicolumn{9}{|l|}{2005} \\
\hline Pre-monsoon & 100 & 0 & 0 & 0 & 0 & 22 & 78 & 19 \\
\hline Monsoon & 85 & 5 & 5 & & 22 & 56 & 22 & 14 \\
\hline Post-monsoon & 82 & 0 & 9 & 9 & 50 & 25 & 25 & 14 \\
\hline \multicolumn{9}{|l|}{2006} \\
\hline Pre-monsoon & 100 & 0 & 0 & 0 & 14 & 50 & 36 & 16 \\
\hline Monsoon & 61 & 25 & 14 & 0 & 29 & 64 & 7 & 10 \\
\hline Post-monsoon & 78 & 22 & 0 & 0 & 33 & 50 & 17 & 8 \\
\hline \multicolumn{9}{|l|}{2007} \\
\hline Pre-monsoon & 86 & 14 & 0 & 0 & 18 & 55 & 27 & 21 \\
\hline Monsoon & 76 & 20 & 4 & 0 & 33 & 47 & 20 & 18 \\
\hline Post-monsoon & 75 & 25 & 0 & 0 & 20 & 80 & 0 & 5 \\
\hline \multicolumn{9}{|l|}{2008} \\
\hline Pre-monsoon & 91 & 9 & 0 & 0 & 14 & 29 & 57 & 26 \\
\hline Monsoon & 69 & 19 & 12 & 0 & 46 & 40 & 14 & 8 \\
\hline Post-monsoon & 100 & 0 & 0 & 0 & 20 & 20 & 60 & 10 \\
\hline Means \pm SE & $83.6 \pm 3.7$ & $11.6 \pm 3.0$ & $3.7 \pm 1.5$ & $1.2 \pm 0.8$ & $24.9 \pm 4.1$ & $44.8 \pm 5.3$ & $30.3 \pm 6.8$ & $14.1 \pm 1.8$ \\
\hline
\end{tabular}

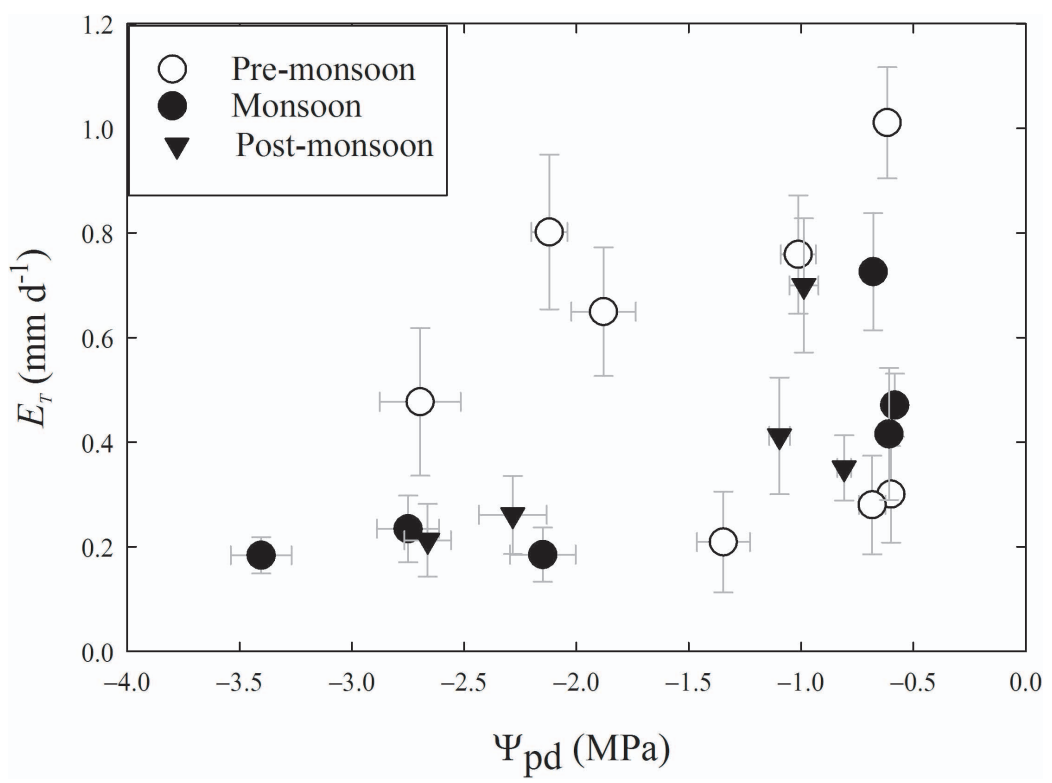

Fig. A1. The relationship between monthly juniper pre-dawn leaf water potential $\left(\Psi_{\mathrm{pd}}\right)$ and $E_{\mathrm{T}}$ by season. The number of data points is limited because not all monthly $\Psi_{\mathrm{pd}}$ observations had corresponding $E_{\mathrm{T}}$ data. 


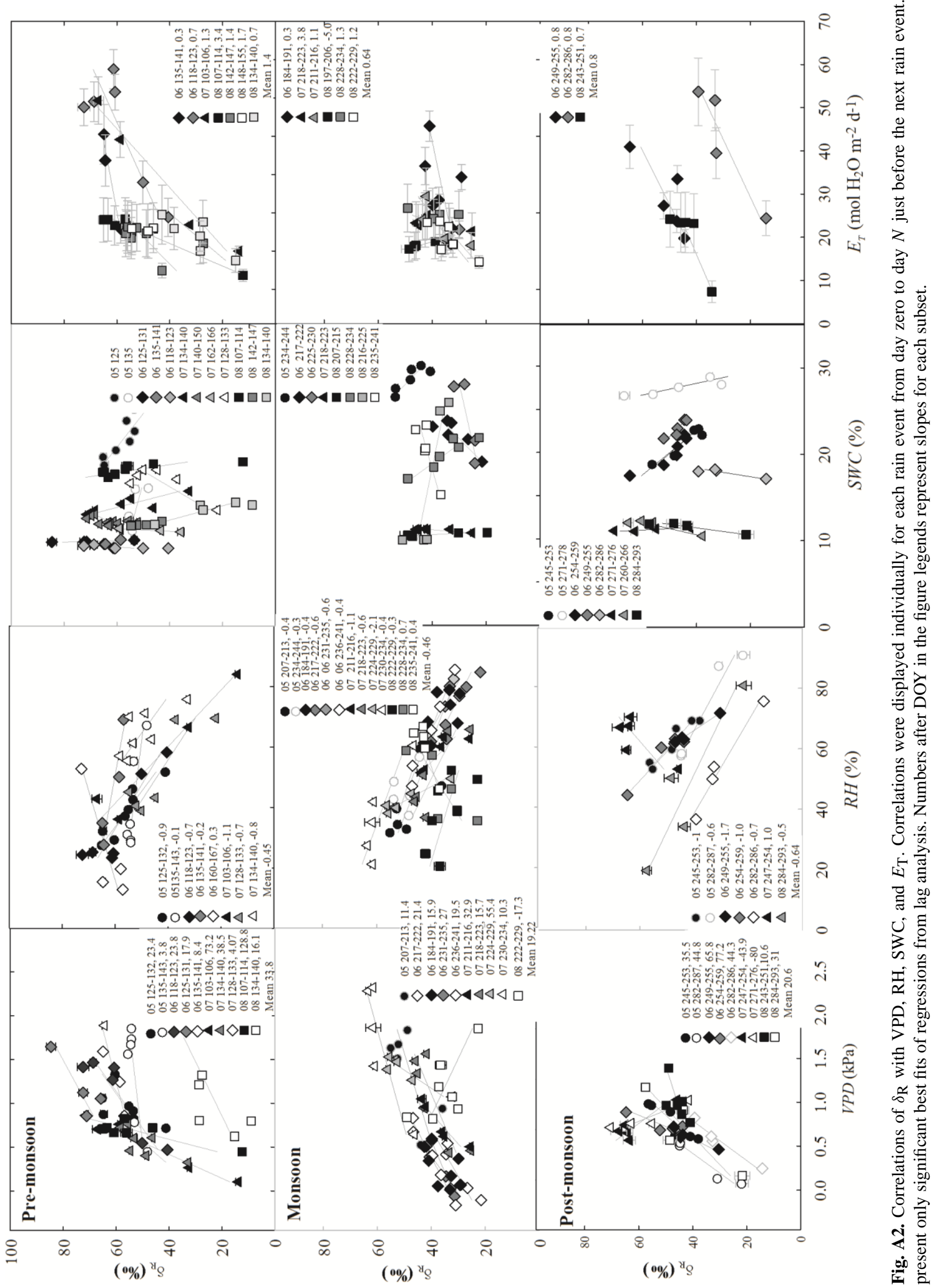




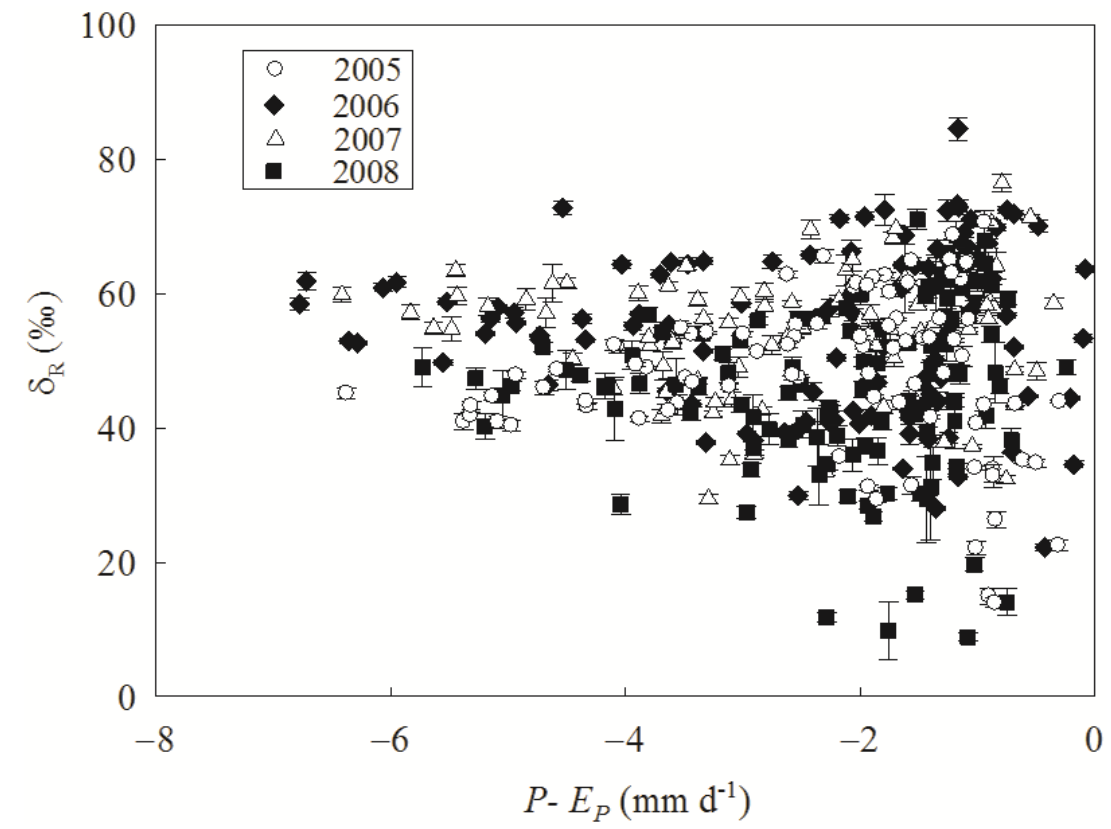

Fig. A3. Relationships between $\delta_{\mathrm{R}}$ and $P-E_{\mathrm{P}}$. All nocturnal Keeling plot intercepts that passed QC criteria from DOY 100 to 273 were included.

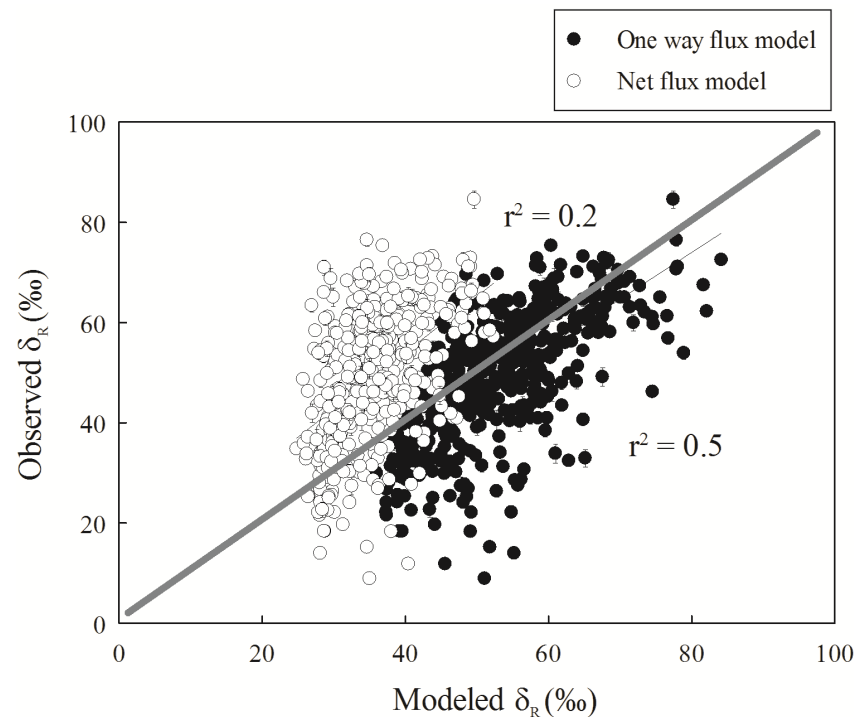

Fig. A4. The relationships between modeled $\delta_{\mathrm{R}}$ and observed $\delta_{\mathrm{R}}$. Dark and open circles represent model output after and before the one-way flux model (Cernusak et al., 2004) was incorporated, respectively. Data are included from DOY 100 to 273.

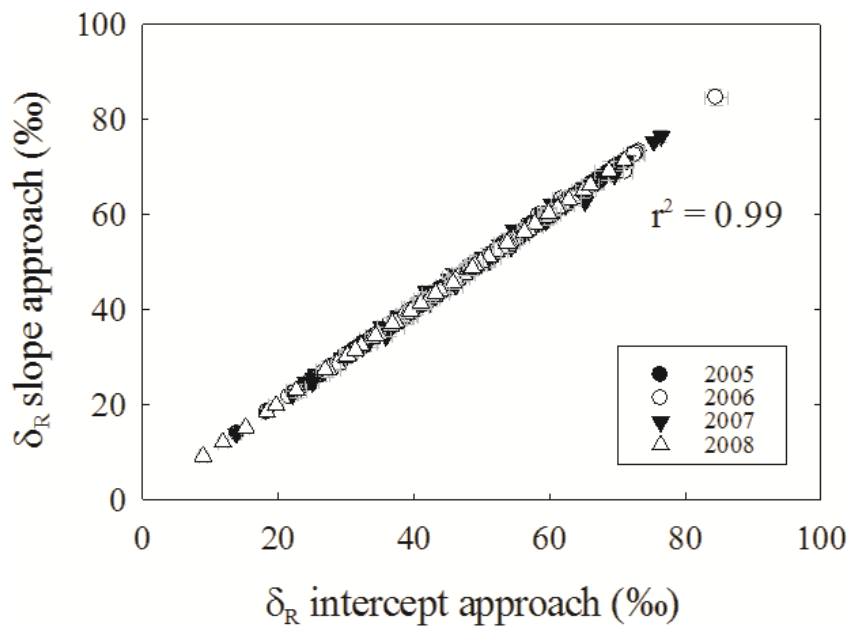

Fig. A5. 1:1 Relationships of $\delta_{\mathrm{R}}$ calculations from the Keeling plots (intercept approach) and Miller/Tans formulation (slope approach). 


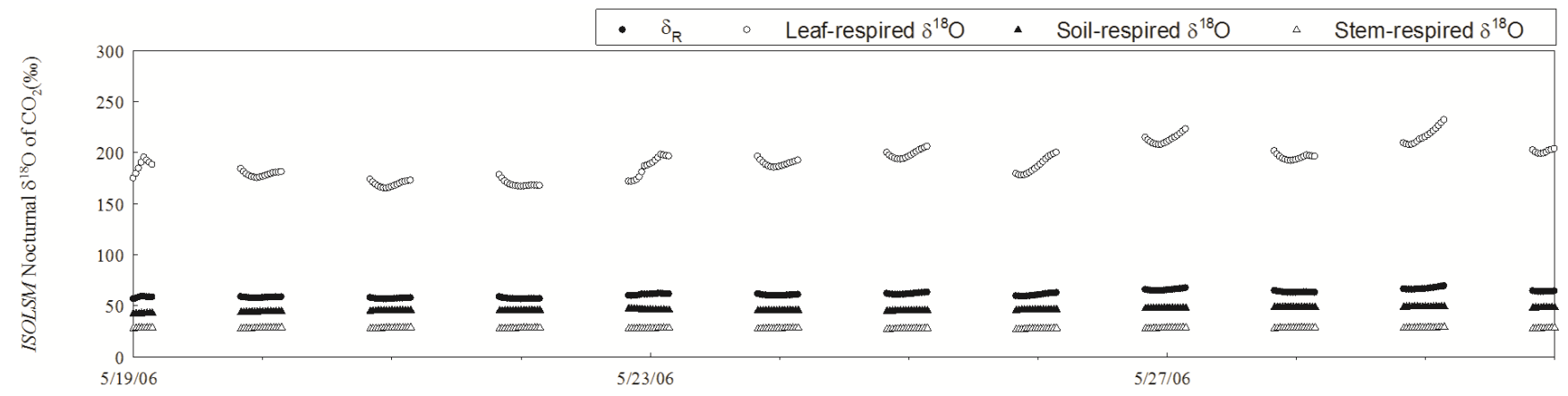

Fig. A6. ISOLSM simulation for nocturnal $\delta_{\mathrm{R}}$ (filled circle), $\delta^{18} \mathrm{O}$ of foliar-respired $\mathrm{CO}_{2}$ (open circle), $\delta^{18} \mathrm{O}$ of soil-respired $\mathrm{CO}_{2}$ (filled triangle) and $\delta^{18} \mathrm{O}$ of stem-respired $\mathrm{CO}_{2}$ (open triangle).

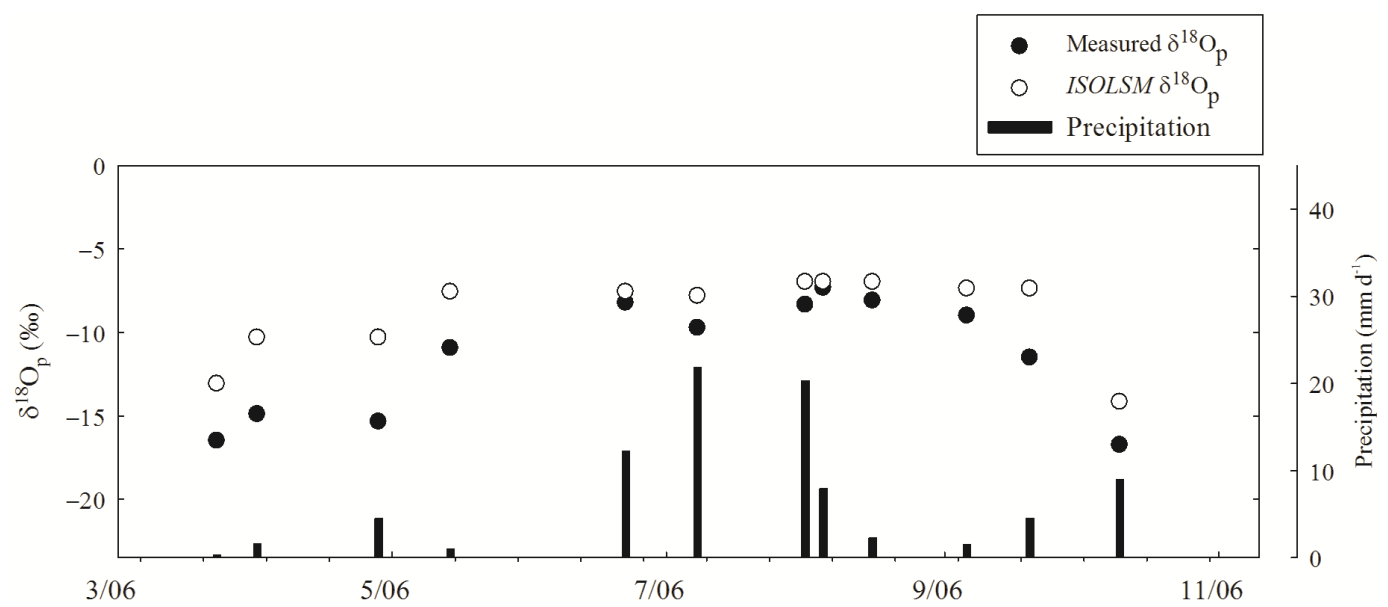

Fig. A7. Pulse precipitation events and associated $\delta^{18} \mathrm{O}$ of precipitation in 2006 for the time periods presented in this manuscript.

Acknowledgements. We appreciate the technical and field support provided by Steve Sargent, Karen Brown, and numerous undergraduate interns during the four years of this study. Funding for this project was derived from LANL-Laboratory Directed Research and Development (LDRD), the Institute for Geophysical and Planetary Research (IGPP), and the Department of Energy, Office of Science, Office of Biological and Environmental Research (DOE-BER).

Edited by: C.-K. Kang

\section{References}

Barbour, M. M., Cernusak, L. A., Whitehead, D., Griffin, K. L., Turnbull, M. H., Tissue, and D. T., and Farquhar, G. D.: Nocturnal stomatal conductance and implications for modeling $\delta^{18} \mathrm{O}$ of leaf-respired $\mathrm{CO}_{2}$ in temperate tree species, Funct. Plant Biol., 32, 1107-1121, 2005.

Bickford, C. P., McDowell, N. M., Erhardt, E. B., and Hanson, D. T.: High frequency field measurements of diurnal carbon isotope discrimination and internal conductance in a semi-arid species, Juniperus monosperma, Plant Cell Environ., 32, 796-810, 2009.

Bickford, C. P., Hanson, D. T., and McDowell, N. G.: Influence of diurnal variation in mesophyll conductance on modelled ${ }^{13} \mathrm{C}$ discrimination: results from a field study, J. Exp. Bot., 61, 32233233, 2010.

Birch, H. F.: Mineralization of plant nitrogen following alternative wet and dry conditions, Plant Soil, 20, 43-49,1964.

Bonan, G. B.: A land surface model (LSM version 1.0) for ecological, hydrological, and atmospheric studies: Technical description and user's guide, 150 pp., NCAR, Boulder, CO., 1996.

Bowling, D. R., McDowell, N. G., Bond B. J., Law, B. E., and Ehleringer, J. R.: ${ }^{13} \mathrm{C}$ content of ecosystem respiration is linked to precipitation and vapor pressure deficit, Oecologia, 131, 113124, 2002.

Bowling, D. R., McDowell, N. G., Welker, J. M., Bond, B. J., Law, B. E., and Ehleringer, J. R.: Oxygen isotope content of $\mathrm{CO}_{2}$ in nocturnal ecosystem respiration: 1 . Observations in forests along a precipitation transect in Oregon, USA, Global Biogeochem. Cy., 17, 1120, doi:10.1029/2003GB002081, 2003a.

Bowling, D. R., Sargent, S. D., Tanner, B. D., and Ehleringer, J. R.: Tunable diode laser absorption spectroscopy for stable isotope studies of ecosystem-atmosphere $\mathrm{CO}_{2}$ exchange, Agr. Forest Meteorol., 118, 1-19, 2003b.

Bowling, D. R., Pataki, D. E., and Randerson, J. T.: Carbon isotopes in terrestrial ecosystem pools and $\mathrm{CO}_{2}$ fluxes, New Phytol., 178, 24-40, 2008. 
Brenninkmeijer, C. A. M., Kraft, P., and Mook, W. G.: Oxygen isotope fractionation between $\mathrm{CO}_{2}$ and $\mathrm{H}_{2} \mathrm{O}$, Isotope Geosciences, 1, 181-190, 1983.

Breshears, D. D., Myers, O. B., Johnson, S. R., Meyer, C. W., and Martens, S. N.: Differential use of spatially heterogeneous soil moisture by two semiarid woody species: Pinus edulis and $\mathrm{Ju}$ niperus monosperma, J. Ecol., 85, 289-299, 1997.

Breshears, D. D., Cobb, N. S., Rich, P. M., Price, K. P., Allen, C. D., Balice, R. G., Romme, W. H., Kastens, J. H., Floyd, M. L., Belnap, J., Anderson, J. J., Myers, O. B., and Meyer, C. W.: Regional vegetation die-off in response to global-change-type drought, $\mathrm{P}$. Natl. Acad. Sci. USA, 102, 15144-15148, 2005.

Buenning, N., Noone, D. C., Riley, W. J., Still, C. J., and White, J. W. C.: Influences of the hydrological cycle on observed interannual variations in atmospheric $\mathrm{CO}^{18} \mathrm{O}$, J. Geophys. Res.Biogeo., 116, G04001, doi:10.1029/2010JG001576, 2011.

Buenning, N., Noone, D. C., Randerson, J. T., Riley, W. J., and Still, C. J.: The response of the ${ }^{18} \mathrm{O}$ content of atmospheric $\mathrm{CO}_{2}$ to changes in environmental conditions, J. Geophys. Res.-Biogeo., in press, 2012.

Cappa, C. D., Hendricks, M. B., DePaolo, D. J., and Cohen, R. C.: Isotopic fractionation of water during evaporation, J. Geophys. Res.-Atmos., 108, 4525, doi:10.1029/2003JD003597, 2003.

Cernusak, L. A., Pate, J. S., and Farquhar, G. D.: Diurnal variation in the stable isotope composition of water and dry matter in fruiting Lupinus angustifolius under field conditions, Plant Cell Environ., 25, 893-907, 2002.

Cernusak, L. A., Wong, S. C., and Farquhar, G. D.: Oxygen isotope composition of phloem sap in relation to leaf water in Ricinus communis, Funct. Plant Biol., 30, 1059-1070, 2003.

Cernusak, L. A., Farquhar, G. D., Wong, S. C., and Stuart-Williams, H.: Measurement and interpretation of the oxygen isotope composition of carbon dioxide respired by leaves in the dark, Plant Physiol., 136, 3350-3363, 2004.

Coplen, T. B.: New guidelines for reporting stable hydrogen, carbon, and oxygen isotope-ratio data, Geochim. Cosmochim. Ac., 60, 3359-3360, 1996.

Cuntz, M., Ciais, P., Hoffmann, G., and Knorr, W.: A comprehensive global three- dimensional model of $\delta^{18} \mathrm{O}$ in atmospheric $\mathrm{CO}_{2}$ 1.Evaluation of surface fluxes, J. Geophys. Res., 108, 4527, doi:10.1029/2002JD003153, 2003a.

Cuntz, M., Ciais, P., Hoffmann, G., Allison, C.E., Francey, R.J., Knorr, W., Tans, P. P., White, J. W. C., and Levin, I.: A comprehensive global three-dimensional model of delta $\mathrm{O}^{18}$ in atmospheric $\mathrm{CO}_{2}$ : 2. Mapping the atmospheric signal, J. Geophys. Res., 108, 4528, doi:10.1029/2002JD003154, 2003 b.

Cuntz, M., Ogée, J., Farquhar, G. D., Peylin, P., and Cernusak, L. A.: Modelling advection and diffusion of water isotopologues in leaves, Plant Cell Environ., 30, 892-909, 2007.

Dawson, T. E. and Ehleringer J. R.: Streamside trees that do not use stream water, Nature, 350, 335-337, 1991.

Dawson, T. E., Burgess, S. S. O., Tu, K. P., Oliveira, R. S., Santiago, L. S., Fisher, J. B., Simonin, K. A., and Ambrose, A. R.: Nighttime transpiration in woody plants from contrasting ecosystems, Tree Physiol., 27, 561-575, 2007.

Ellis, A. W., Goodrich, G. B., and Garfin, G. M.: A hydroclimatic index for examining patterns of drought in the Colorado River Basin, Int. J. Climatol., 30, 236-255, 2010.
Farquhar, G. D. and Cernusak, L.A .: On the isotopic composition of leaf water in the non-steady state, Funct. Plant Biol., 32, 293303, 2005.

Farquhar, G. D. and Lloyd J.: Carbon and oxygen isotope effects in the exchange of carbon dioxide between plants and the atmosphere, in: Stable Isotopes and Plant Carbon - Water Relations, edited by: Ehleringer, J. R., Hall, A. E. and Farquhar, G. D., 4770, Academic Press, New York, USA, 1993.

Farquhar, G. D., Lloyd, J., Taylor, J. A., Flanagan, L. B., Syvertsen, J. P, and Ehleringer, J. R.: Vegetation effects on the isotope composition of oxygen in atmospheric $\mathrm{CO}_{2}$, Nature, 363, 493-443, 1993.

Ferrio, J. P., Cuntz, M., Offermann, C., Siegwolf, R., Saurer, M., and Gessler, A.: Effect of water availability on leaf water isotopic enrichment in beech seedlings shows limitations of current fractionation models, Plant Cell Environ., 32, 1285-1296, 2009.

Flanagan, L. B., Brooks, J. R., Varney, G. T., Berry, S. C., and Ehleringer, J. R.: Carbon isotope discrimination during photosynthesis and the isotope ratio of respired $\mathrm{CO}_{2}$ in boreal forest ecosystems, Global Biogeochem. Cy., 10, 629-640, 1996.

Flanagan, L. B., Brooks, J. R., Varney, G. T., and Ehleringer, J. R.: Discrimination against $\mathrm{C}^{18} \mathrm{O}^{16} \mathrm{O}$ during photosynthesis and the oxygen isotope ratio of respired $\mathrm{CO}_{2}$ in boreal forest ecosystems, Global Biogeochem. Cy., 11, 83-98, 1997.

Francey, R. J. and Tans, P. P.: Latitudinal variation in oxygen-18 of atmospheric $\mathrm{CO}_{2}$, Nature, 327, 495-497, 1987.

Fung, I., Field, C. B., Berry, J. A., Thompson, M. V., Randerson, J. T., Malmström, C. M., Vitousek, P. M., Collatz, G. J., Sellers, P. J., Randall, D. A., Denning, A. S., Badeck, F., and John, J. : Carbon 13 exchanges between the atmosphere and biosphere, Global Biogeochem. Cy., 11, 5070-533, 1997.

Gillon, J. S. and Yakir, D.: Naturally low carbonic anhydrase activity in $\mathrm{C}_{4}$ and $\mathrm{C}_{3}$ plants limits discrimination against $\mathrm{C}^{18} \mathrm{OO}$ during photosynthesis, Plant Cell Environ., 23, 903-915, 2000.

Granier, A.: Evaluation of transpiration in a Douglas-fir stand by means of sap flow measurements, Tree Physiol., 3, 309-319, 1987.

Griffis, T. J., Lee, X., Baker, J. M., Sargent, S. D., and King, J. Y.: Feasibility of quantifying ecosystem-atmosphere $\mathrm{C}^{18} \mathrm{O}^{16} \mathrm{O}$ exchange using laser spectroscopy and the flux-gradient method, Agr. Forest Meteorol., 135, 44-60, 2005.

Hamon, W. R.: Estimating potential evapotranspiration, Proceedings of the American Society of Civil Engineering, 871, 107120, 1961.

Helliker, B. R., Roden, J. R., Cook, C., and Ehleringer, J. R.: A rapid and precise method for sampling and determining the oxygen isotope ratio of atmospheric water vapor, Rapid Commun. Mass Sp., 16, 929-932, 2002

Henderson-Sellers, A., Fischer, M., Aleinov, I., McGuffie, K., Riley, W. J., Schmidt, G. A., Sturm, K., Yoshimura, K., and Irannejad, P.: Stable water isotope simulation by current land-surface schemes: Results of iPILPS Phase 1, Global Planet. Change, 51, 34-58, 2006.

Huxman, T. E., Wilcox, B. P., Breshears, D. D., Scott, R. L., Snyder, K. A., Small, E. E., Hultine, K., Pockman, W. T., and Jackson, R.B .: Ecohydrological implications of woody plant encroachment, Ecology, 86, 308-319, 2005.

Keeling, C. D.: The concentration and isotopic abundances of atmospheric carbon dioxide in rural areas, Geochim. Cosmochim. 
Ac., 13, 322-334, 1958.

Lai, C.-T., Ehleringer, J. R., Tans, P. P., Wofsy, S., Urbanski, S., and Hollinger, D.: Estimating photosynthetic $13 \mathrm{C}$ discrimination in terrestrial $\mathrm{CO}_{2}$ exchange from canopy to regional scales, Global Biogeochem. Cy., 18, GB1041, doi:10.1029/2003GB002148, 2004.

Lai, C.-T., Riley, W., Owensby, C., Ham, J., Schauer, A., and Ehleringer, J. R.: Seasonal and interannual variations of carbon and oxygen isotopes of respired $\mathrm{CO}_{2}$ in a tallgrass prairie: Measurements and modeling results from 3 years with contrasting water availability, J. Geophys. Res.-Atmos., 111, D08S06, doi:10.1029/2005JD006436, 2006.

Lajtha, K. and Barnes, F. J.: Carbon gain and water-use in pinyon pine-juniper woodlands of northern New Mexico - field versus phytotron chamber measurements, Tree Physiol., 9, 59-67, 1991.

Lee, X.,Smith, R., and Williams J.: Water vapor ${ }^{18} \mathrm{O} /{ }^{16} \mathrm{O}$ isotope ratio in surface air in New England, USA, Tellus, 58B, 293-304, 2006.

Lynch, J. A., Grimm, J. W., and Bowersox, V. C.: Trends in precipitation chemistry in the United States: A national perspective, 1980-1992, Atmos. Environ., 29, 1231-1246, doi:10.1016/13522310(94)00371-Q, 1995.

Mathieu, R. and Bariac, T.: An isotopic study $\left({ }^{2} \mathrm{H}\right.$ and $\left.{ }^{18} \mathrm{O}\right)$ of water movements in clayey soils under a semi-arid climate, Water Resour. Res., 32, 779-789, 1996.

McDowell, N. G., White, S., and Pockman, W. T.: Transpiration and stomatal conductance across a steep climate gradient in the southern Rocky Mountains, Ecohydrology, 1, 193-204, 2008a.

McDowell, N. G., Baldocchi, D., Barbour, M., Bickford, C., Cuntz, M., Hanson, D., Knohl, A., Powers, H., Rahn, T., Randerson, J., Riley, W. J., Still, C., Tu, K., and Walcroft, A.: Understanding the Stable Isotope Composition of Biosphere-Atmosphere $\mathrm{CO}_{2}$ Exchange, Eos, 89, 94-95, 2008b.

McDowell, N. G., Bowling, D. R., Schauer, A., Irvine, J., Bond, B. J., Law, B. E., and Ehleringer, J. R.: Associations between carbon isotope ratios of ecosystem respiration, water availability and canopy conductance, Glob. Change Biol., 10, 1767-1784, 2004.

Miller, J. B. and Tans, P. P.: Calculating isotopic fractionation from atmospheric measurements at various scales, Tellus B, 55, 207214, 2003.

Miller, J. B., Yakir, D., White, J. W. C., and Tans, P. P.: Measurement of ${ }^{18} \mathrm{O} /{ }^{16} \mathrm{O}$ in the soil-atmosphere $\mathrm{CO}_{2}$ flux, Global Biogeochem. Cy., 13, 761-774, 1999.

Newman, B. D. and Robinson, B. A.: The hydrogeology of Los Alamos National Laboratory: site history and overview of vadose zone and groundwater issues, Vadose Zone J., 4, 614-619, 2005.

Ogée, J., Peylin, P., Cuntz, M., Bariac, T., Brunet, Y., Berbigier, P., Richard, P., and Ciais, P.: Partitioning net ecosystem carbon exchange into net assimilation and respiration with canopyscale isotopic measurements: An error propagation analysis with $\left(\mathrm{CO}_{2}\right)-\mathrm{C}^{13}$ and $(\mathrm{COO})-\mathrm{O}^{18}$ data, Global Biogeochem. Cy., 18, GB2019, doi:10.1029/2003GB002166, 2004.

Phillips, N. and Oren, R.: Intra- and inter-annual variation in transpiration of a pine forest in relation to environmental variability and canopy development, Ecol. Appl., 11, 385-396, 2001.

Powers, H. H., Hunt, J. E., Hanson, D. T., and McDowell, N. G.: A dynamic soil chamber system coupled with a tunable diode laser for online measurements of $\delta^{13} \mathrm{C}$ and $\delta^{18} \mathrm{O}$ of soil respired $\mathrm{CO}_{2}$, Rapid Commun. Mass Sp., 24, 243-253, 2010.

Rauscher, S. A., Giorgi, F., Diffenbaugh, N. S., and Seth, A.: Extension and Intensification of the Meso-American mid-summer drought in the twenty-first century, Clim. Dynam., 31, 551-571, 2008.

Reynolds, J. F., Kemp, P. R., and Tenhunen, J. D.: Effects of longterm rainfall variability on evapotranspiration and soil water distribution in the Chihuahuan Desert: A modeling analysis, Plant Ecol., 150, 145-159, 2000.

Reynolds, J. F., Kemp, P. R., Ogle, K., and Fernandez, R. J.: Modifying the 'pulse-reserve' paradigm for deserts of North America: precipitation pulses, soil water, and plant responses, Oecologia, 141, 194-210, 2004.

Rich, P. M., Breshears, D. D., and White, A. B.: Phenology of mixed woody-herbaceous ecosystems following extreme events: net and differential responses, Ecology, 89, 342-352, 2008.

Riley, W. J.: A modeling study of the impact of the $\delta^{18} \mathrm{O}$ value of near-surface soil water on the $\delta^{18} \mathrm{O}$ value of the soil-surface $\mathrm{CO}_{2}$ flux, Geochim. Cosmochim. Ac., 69, 1939-1946. 2005.

Riley, W. J. and Still, C. J.: Constraints on the use of ${ }^{18} \mathrm{O}$ in $\mathrm{CO}_{2}$ as a tracer to partition gross carbon fluxes, paper presented at American Geophysical Union, 10-14 December, San Francisco, CA, 2003.

Riley, W. J., Still, C. J., Torn, M. S., and Berry, J. A.: A mechanistic model of $\mathrm{H}_{2}^{18} \mathrm{O}$ and $\mathrm{C}^{18} \mathrm{OO}$ fluxes between ecosystems and the atmosphere: Model description and sensitivity analyses, Global Biogeochem. Cy., 16, 1095-1109, 2002.

Roden, J. S. and Ehleringer, J. R.: Observations of hydrogen and oxygen isotopes in leaf water confirm the Craig-Gordon model under wide-ranging environmental conditions, Plant Physiol., 120, 1165-1173, 1999.

Rozanski, K. C., Sonntag, C., and Munnich, K. O.: Factors controlling stable isotope composition of European precipitation, Tellus, 34, 142-150, 1982.

Schaeffer, S. M., Miller, J. B., Vaughn, B. H., White, J. W. C., and Bowling, D. R.: Long-term field performance of a tunable diode laser absorption spectrometer for analysis of carbon isotopes of $\mathrm{CO}_{2}$ in forest air, Atmos. Chem. Phys., 8, 5263-5277, doi:10.5194/acp-8-5263-2008, 2008.

Schwalm, C. R., Williams, C. A., Schaefer, K., Anderson, R., Arain, M. A., Baker, I., Barr, A., Black, T. A., Chen, G., Chen, J.M., Ciais, P., Davis, K. J., Desai, A., Dietze, M., Dragoni, D., Fischer, M.L., Flanagan, L.B., Grant, R., Gu, L.H., Hollinger, D., Izaurralde, R. C., Kucharik, C., Lafleur, P., Law, B.E., Li, L.H., Li, Z.P., Liu, S. G., Lokupitiya, E., Luo, Y. Q., Ma, S. Y., Margolis, H., Matamala, R., McCaughey, H., Monson, R. K., Oechel, W.C., Peng, C. H., Poulter, B., Price, D.T., Riciutto, D. M., Riley, W., Sahoo, A. K., Sprintsin, M., Sun, J. F., Tian, H. Q., Tonitto, C., Verbeeck, H., and Verma, S. B.: A model-data intercomparison of $\mathrm{CO}_{2}$ exchange across North America: Results from the North American Carbon Program site synthesis, J. Geophys. Res.-Biogeo., 115, G00H05, doi:10.1029/2009JG001229, 2010.

Seager, R., Ting,M., Held, I., Kushnir, Y., Lu, J., Vecchi, G., Huang, H.-P., Harnik, N., Leetmaa, A., Lau, N.-C., Li, C., Velez, J., and Naik, N.: Model Projections of an Imminent Transition to a more Arid Climate in Southwestern North America, Science, 316, 1181-1184, 2007 
Seibt, U., Wingate, L., Lloyd, J., and Berry, J. A.: Diurnally variable $\delta^{18} \mathrm{O}$ signatures of soil $\mathrm{CO}_{2}$ fluxes indicate carbonic anhydrase activity in a forest soil, J. Geophys. Res., 111, G04005, doi:10.1029/2006JG000177, 2006.

Sharp, Z. D.: Principles of Stable Isotope Geochemistry, Prentice Hall, 344 pp., 2005.

Shim, J. H., Powers, H. H., Meyer, C. W., Pockman, W. T., and McDowell, N. G.: The role of inter-annual, seasonal, and synoptic climate on the carbon isotope ratio of ecosystem respiration at a semi-arid woodland, Glob. Change Biol., 17, 2584-2600, doi:10.1111/j.1365-2486.2011.02454.x, 2011.

Still, C. J., Riley, W. J., Helliker, B. A., and Berry, J. A.: Simulation of ecosystem oxygen-18 $\mathrm{CO}_{2}$ isotope fluxes in a tallgrass prairie: Biological and physical controls, in: Stable Isotopes and Biosphere-Atmosphere Interactions, edited by: Flanagan, L. B., Ehleringer, J. R., and Pataki, D. E., Elsevier-Academic Press, 2005.

Still, C. J., Riley, W. J., Biraud, S. C., Noone, D. C., Buenning, N. H., Randerson, J. T., Torn, M. S., Welker, J., White, J. W. C., Vachon, R., Farquhar, G. D., and Berry, J. A.: Influence of clouds and diffuse radiation on ecosystem-atmosphere $\mathrm{CO}_{2}$ and $\mathrm{CO}^{18} \mathrm{O}$ exchanges, J. Geophys. Res.-Biogeo., 114, G01018, doi:10.1029/2007JG000675, 2009.

Tang, J. Y. and Zhuang, Q. L: Equifinality in parameterization of process-based biogeochemistry models: A significant uncertainty source to the estimation of regional carbon dynamics, J. Geophys. Res.-Biogeo., 113, G04010, doi:10.1029/2008jg000757, 2008.

Tans, P. P.: Oxygen isotopic equilibrium between carbon dioxide and water in soils, Tellus B, 50, 163-178, 1998.

Tans, P. P. and White, J. W. C.: In balance, with a little help from the plants, Science, 281, 183-184, 1998.

Walker, G. R., Hughes, M. W., Allison, G. B., and Barnes, C. J.: The movement of isotopes of water during evaporation from a bare soil surface, J. Hydrol., 97, 181-197, 1988.

Wang, X.-F. and Yakir, D.: Temporal and spatial variations in the oxygen-18 content of leaf water in different plant species, Plant Cell Environ., 18, 1377-1385, 1995

Welker, J. M.: Isotopic (delta $\mathrm{O}^{18}$ ) characteristics of weekly precipitation collected across the USA: an initial analysis with application to water source studies, Hydrol. Process., 14, 1449-1464, 2000.
Welp, L. R., Randerson, J. T., and Liu, H. P.: Seasonal exchang of $\mathrm{CO}_{2}$ and $\delta^{18} \mathrm{O}-\mathrm{CO}_{2}$ vaires with postfire succesion in boreal forest ecosystems, J. Geophys. Res., 111, G03007, doi:10.1029/2005JG000126, 2006.

Welp, L. R., Keeling, R. F., Meijer, H. A. J., Bollenbacher, A. F., Piper, S. C., Yoshimura, K., Francey, R. J., Allison, C. E., and Wahlen, M.: Interannual variability in the oxygen isotopes of atmospheric $\mathrm{CO}_{2}$ driven by El Nino, Nature, 477, 579-582, 2011.

Weltzin, J. F. and Tissue, D. T.: Resource pulses in arid environments - patterns of rain, patterns of life, New Phytol., 157, 171173, 2003.

White, J. W. C. and Gedzelman, S. D.: The isotope composition of atmospheric water vapor and the concurrent meteorological conditions, J. Geophys. Res., 89, 4937-4939, doi:10.1029/JD089iD03p04937, 1984.

Wilson, K. B., Hanson, P. J., Mulholland, P. J., Baldocchi, D. D., and Wullschleger, S. D.: A comparison of methods for determining forest evapotranspiration and its components: sap-flow, soil water budget, eddy covariance and catchment water balance, Agr. Forest Meteorol., 106, 153-168, 2001.

Wingate, L., Ogée, J., Cuntz, M., Genty, B., Reiter, I., Seibt, U., Yakir, D., Peylin, P., Miller, J., Burlett, R., Maseyk, K., Mencuccini, M., Pendall, E., Shim, J. H., Barbour, M., Hunt, J., Mortazavi, B., and Grace, J.: The impact of soil microorganisms on the global budget of delta $\mathrm{O}^{18}$ in atmospheric $\mathrm{CO}_{2}$, P. Natl. Acad. Sci. USA, 106, 22411-22415, doi:10.1073/pnas.0905210106, 2009.

Wingate, L., Ogée, J., Burlett, R., and Bosc, A.: Strong seasonal ${ }^{18} \mathrm{O}$ disequilibrium between leaf and soil $\mathrm{CO}_{2}$ fluxes, Glob. Change Biol., 16, 3048-3064, doi:10.1111/j.1365-2486.2010.02186.x, 2010.

Yakir, D. and Wang, X.-F.: Fluxes of $\mathrm{CO}_{2}$ and water between terrestrial vegetation and the atmosphere estimated from isotope measurements, Nature, 380, 515-517, 1996.

Zobitz, J. M., Keener, J. P., Schnyder, H., and Bowling, D. R.: Sensitivity analysis and quantification of uncertainty for isotopic mixing relationships in carbon cycle research, Agr. Forest Meteorol., 136, 56-75, 2006. 